\title{
AUNC
}

Zabytkoznawstwo i Konserwatorstwo XLVII

Toruń 2016

DOI: http://dx.doi.org/10.12775/AUNC_ZiK.2016.011

\section{Mieszaniny z błękitem pruskim - zagadnienia trwałości barwy zielonych i błękitnozielonych warstw malarskich w malarstwie i konserwacji}

\section{ELŻBIETA SZMIT-NAUD}

Zakład Konserwacji Malarstwa i Rzeźby Polichromowanej, Wydział Sztuk Pięknych, UMK w Toruniu

e-mail: esn@umk.pl

Key words: Prussian Blue, pigment mixtures lightfastness, accelerated ageing, colour change assessment

Słowa kluczowe: błękit pruski, światłotrwałość mieszanin pigmentów, przyspieszone starzenie, ocena zmian barwy

\begin{abstract}
Mixtures with Prussian Blue - colour permanence of green and blue-greenish paint layers in painting and in conservation-restoration

Pigments individually characterized with an acceptable lightfastness do not always retain that characteristics when mixed on a palette by a painter or conservator-restorer. The awareness of this phenomenon is useful both while interpreting the appearance of a paint layer of pictures suggesting that some changes unintended by the artist have occurred, and while performing reintegration of damaged paint layers. Earlier preliminary research, in part already published, of several of such mixtures reported as unstable in painting manuals allowed to identify some of them containing Prussian Blue prone to distinct alterations. The subsequent tests and further observations made over the period of several years prompted the author to the conclusion, that the problem extends beyond the limits of such a simple ascertainment. Further examinations reported in this paper concerned several of such mixtures used to
\end{abstract}


obtain green and greenish-blue hues tested in perspective of their potential use in painting restoration, with two different binders and with the admixture of white pigment or extender in order to allow for the assessment of lightened tone. The examination consisted on accelerated ageing (light exposure) of the obtained paint layers together with documentation of their condition at several stages (photographic and colorimetric records). Attempts were made for a preliminary identification of the mechanisms of changes based on the analysis of the results of IR- and Raman-spectroscopy of several samples. The direction of further research has been established, that would possibly allow for a more comprehensive interpretation of the observed phenomena. In the same time certain conclusions important for restoration practice, (possible to enunciate at this stage of research) have been presented.

\section{Abstrakt}

Mieszaniny tworzone na palecie malarza lub konserwatora z pigmentów pojedynczo charakteryzujących się wystarczającą światłotrwałością nie zawsze utrzymują tę cechę $\mathrm{w}$ mieszaninie. Wiedza o tym jest przydatna zarówno przy interpretacji wyglądu warstwy malarskiej obrazów, sugerującego zajście zmiany niezamierzonej przez autora, jak i podczas wykonywania uzupełnień ubytków. Wcześniejsze wstępne badania - częściowo relacjonowane - kilku takich mieszanin, wzmiankowanych jako niestabilne w podręcznikach malarstwa, pozwoliły wyłonić kilka substancji zawierających błękit pruski i podlegających wyraźnym zmianom. Kolejne testy i dalsze obserwacje, dokonane z perspektywy kilku lat, skłoniły do stwierdzenia, że problem wykracza poza tę prostą konstatację. Kolejne badania, zrelacjonowane w poniższym tekście, dotyczyły kilku mieszanin służących do uzyskiwania tonów zielonych i zielonkawobłękitnych, testowanych w perspektywie ich potencjalnego użycia w restauracji malarstwa, z dwoma różnymi spoiwami i z użyciem białego pigmentu lub wypełniacza w celu umożliwienia oceny tonu rozjaśnionego. Badania objęły przyspieszone starzenie w świetle otrzymanych warstw malarskich, z udokumentowaniem ich stanu na kolejnych etapach - ilustracyjnie i barwometrycznie. Podjęto wstępną próbę określenia mechanizmu stwierdzonych zmian na podstawie analizy widm spektroskopii IR i ramanowskiej kilku próbek. Wskazano kierunek dalszych badań, które mogłyby pozwolić na pełniejszą interpretację obserwowanych zjawisk, jednocześnie przedstawiając wnioski istotne dla konserwatorskiej praktyki, które na obecnym etapie można sformułować.

Mieszaniny tworzone na palecie malarza lub konserwatora z pigmentów pojedynczo charakteryzujących się wystarczającą światłotrwałością nie zawsze utrzymują tę cechę w mieszaninie. Wiedza o tym jest przydatna zarówno do interpretacji wyglądu warstwy malarskiej obrazów sugerującego zmianę niezamierzoną przez autora, jak i podczas uzupełniania ubytków. Wcześniejsze 
wstępne badania autorki - częściowo relacjonowane ${ }^{1}$ - kilku takich mieszanin, znanych z ostrzeżeń zawartych w podręcznikach malarstwa, pozwoliły wyróżnić niektóre z nich, zawierające błękit pruski i podlegające wyraźnym zmianom. Opublikowane rezultaty innych badań błękitu pruskiego, kolejne testy i dalsze obserwacje ${ }^{2}$, dokonane z perspektywy kilku lat, skłoniły do stwierdzenia, że problem wykracza poza tę prostą konstatację. Podjęcie dalszych poszukiwań, istotnych zwłaszcza z punktu widzenia możliwości stosowania błękitu pruskiego w pracach restauratorskich, miało na celu weryfikację wcześniejszych spostrzeżeń i ustalenie, na ile skład barwnej mieszaniny, dodatek bieli o różnej charakterystyce widmowej i rodzaj substancji błonotwórczej może wpływać na intensywność zmian.

\section{Błękit pruski - składnik palety malarskiej}

(metody produkcji i dodatki wpływające na jego stabilność)

Błękit pruski otwiera listę pigmentów uzyskiwanych na drodze syntezy. Był dziełem przypadku - otrzymał go w 1704 roku berliński wytwórca farb Jacob Diesbach w wyniku zanieczyszczenia potażu podczas zamierzonej produkcji czerwonego laku z koszenili.

Intensywność barwy nowego niebieskiego produktu uczyniła zeń pigment wart udoskonalenia receptury i komercjalizacji, będący alternatywą dla błękitów obecnych na paletach do tego czasu: mineralnych, tracących intensywność w miarę rozdrabniania (jak smalta i azuryt ${ }^{3}$ ) lub drogich (jak ultramaryna), bądź organicznych, nie dość trwałych (jak indygo). Odtąd w różnych odmianach i pod różnymi nazwami, wskazującymi na miejsce produkcji, producenta albo zwyczajowe użycie, błękit pruski znalazł trwałe miejsce na malarskiej palecie - jako błękit pruski, berliński, paryski, chiński, antwerpski, Milori, Turnbulla, niebieski charron, błękit nieba lub Marii-Luizy, by wymienić tylko kilka z nich ${ }^{4}$.

1 Elżbieta Szmit-Naud, „Stabilność barwna mieszanin pigmentów stosowanych we współczesnej palecie”, Ochrona Zabytków 3/4 (2004): 95-98.

2 Uzyskane podczas realizacji grantu UMK 496-Z „Warstwy malarskie z mieszanin pigmentów - próby określenia przyczyn nietrwałości barwy w procesie starzenia” w 2005 r. oraz kolejne, dotąd niepublikowane.

3 W gatunkach zwanych „popiołowymi” z tego właśnie powodu.

4 Sądzono, że mieszcząc się w grupie pigmentów żelazowo-cyjanowych, błękity te różnią się strukturą chemiczną; np. uważano, że paryski Milori i Turnbulla zawierają żelazocyjanki żelazawe - zob. np. Jan Hopliński, Farby i spoiwa malarskie (Wrocław: Ossolineum, 1990), 164. Zgodnie z ostatnią wiedzą, są one żelazocyjankami żelazowymi (zarówno pruski, jak 
Udokumentowany przykład użycia nowego pigmentu w malarstwie sztalugowym sięga już roku 1709 - posłużył się nim Pieter van der Werff w obrazie Złożenie do grobu 5 . Twórcami, którzy w swoich dziełach wykorzystali bogate możliwości, jakie wniósł ten nowy składnik palety jeszcze przed opublikowaniem metody jego wytwarzania w 1724 roku, byli następnie Watteau, Pater i Lancret, prawdopodobnie także Boucher i Fragonard, malarze dworu pruskiego w Poczdamie, Canaletto, później zaś Tiepolo, Gainsborough, Hogarth, Guardi ${ }^{6}$, Vigée-Lebrun i kolejni, po XX stulecie. Upowszechnione od lat siedemdziesiątych XX wieku błękity ftalocyjaninowe, którymi jest zastępowany, nie wyrugowały go z palety całkowicie, więc i w naszych czasach może się znaleźć zarówno na palecie malarza, jak i konserwatora, choć nie w postaci, jaką miał w pierwszym okresie jego produkcji.

Do połowy XIX wieku błękit pruski otrzymywano używając jako substratów suszonej krwi bydlęcej (czasem, w późniejszych recepturach, prażonych kopyt), wodorowinianu i azotanu potasu lub innych alkaliów, ałunu i zielonego witriolu (uwodnionego siarczanu żelaza) ${ }^{7}$. Proporcje poszczególnych surowców były arbitralnie dobierane, co rzutowało na finalny produkt. Badania kilku błękitów pruskich laboratoryjnie zsyntetyzowanych zgodnie z dawnymi recepturami wykazały w nich obecność pierwiastków niezwiązanych ze strukturą błękitu pruskiego, stanowiących zanieczyszczenia - przede wszystkim glinu (od kilku do niemal 30\% wag.) wskutek użycia ałunu, w znacznie

i Turnbulla); ustalono to dzięki analizom dostępną od lat 60. XX w. metodą spektroskopii Mössbauera wraz z badaniami metodą dyfrakcji rentgenowskiej. Błękity antwerpski, nieba, Marii-Luizy oraz charron (lub „de charette” - od regionalnego zwyczaju malowania wozów na niebiesko) były mieszane z białymi wypełniaczami. Obecnie ten ostatni (blue charron) nie zawiera błękitu pruskiego, a kobaltowy. Inne synonimy błękitu pruskiego zob. Nicholas Eastaugh et al., Pigment Compendium. A Dictionary and Optical Microscopy of Histoical Pigments (Amsterdam: Elsevier, 2008), 315.

5 Jens Bartoll i Jackisch Bärbel, “Prussian Blue. A Chronology of the Early Years”, Zeitschrift für Kunsttechnologie und Konservierung 24 (2010) 1: 88.

6 Jo Kirby, "Fading and Colour Change of Prussian Blue: Occurrences and Early Reports", National Gallery Technical Bulletin 14 (1993): 63, http://www.nationalgallery.org.uk/technical-bulletin/kirby199 (dostęp 7 października 2016); Jo Kirby i David Saunders, “Fading and Colour Change of Prussian Blue: Methods of Manufacture and the Influence of Extenders”, National Gallery Technical Bulletin 25 (2004): 89, 96-98, http://www.nationalgallery. org.uk/technical-bulletin/kirby_saunders2004 (dostęp 7 października 2016); David Bomford i Ashok Roy, “Canaletto' Stonemason's Yard and San Simeone Piccolo", National Gallery Technical Bulletin 14 (1993): 38, http://www.nationalgallery.org.uk/technical-bulletin/bomford_roy1993 (dostęp 7 października 2015).

7 Zgodnie z XVIII-wiecznymi recepturami, które opublikowali Kirby i Saunders, "Fading and Colour”, 75, 94-95; Chiharu Asai, "Handmade Berlinerblau”, Zeitschrift für Kunsttechnologie und Konservierung 18 (2005) 2: 261-292. 
mniejszym stopniu siarki i fosforu pochodzących z surowca - suszonej krwi, ułamków procenta krzemu i chloru ${ }^{8}$.Zdarzało się, już na etapie produkcji, że umyślnie modyfikowano jego odcień dodatkiem czerwonych laków, np. z koszenili lub szafranu barwierskiego ${ }^{9}$, nie była to jednak, jak można sądzić na podstawie opisu receptur, powszechna praktyka. W dziewiętnastowiecznych produktach odnotowano dodatki, których zadaniem było poprawienie właściwości aplikacyjnych błękitu pruskiego ${ }^{10}$. Pigment ten np. w akwareli podczas wysychania warstwy, mimo bardzo dobrego roztarcia, wykazywał tendencję do „zbiegania się”, dlatego, by zapewnić lepsze zdyspergowanie cząsteczek i zapobiec ich flokulacji, w trakcie ucierania farby dodawano skrobi ${ }^{11}$.

Obecność tego i innych wypełniaczy w osiemnasto- i dziewiętnastowiecznych pigmentach lub farbach określanych mianem błękitu pruskiego nie musiała oznaczać fałszerstwa ani produktu pośledniejszej jakości. Siła barwienia czystego błękitu pruskiego jest tak duża, że stosowanie go w pełnym tonie, w którym ma niemal czarny wygląd, nie eksponuje jego właściwości barwnych. Dodatek wypełniaczy, dzięki rozcieńczeniu pozwalających wydobyć barwę, był powszechną praktyką i z użytkowego punktu widzenia nie zasługuje na naganę. Wypełniacz w postaci wodorotlenku glinu mógł być zawarty automatycznie w produktach powstających zgodnie z dawną recepturą, z powodu użycia ałunu ${ }^{12}$. Siarczan baru mógł być dodawany już w trakcie strącania błękitu pruskiego, tj. wytrącany razem z nim w odmianach z połowy XIX wieku, takich jak „błękit nieba” bądź „błękit Marii-Luizy”. Do „błękitu charron” dodawano siarczanu baru w procesie mielenia, „błękit antwerpski” mógł zawierać błękit pruski mieszany z kilkoma wypełniaczami - wodorotlenkiem glinu, węglanem magnezu i tlenkiem cynku ${ }^{13}$. Jako wypełniacze

8 Louise Samain, “Degradation Mechanism of Prusian Blue Pigments in Paint Layers” (rozprawa doktorska, Université de Liège, 2012), 112, http://bictel.ulg.ac.be/ETD-db/collection/ available/ULgetd-03052012-112020 (dostęp 7 października 2016). Określone metodą analizy PIXE (Particle Induced X-Ray Emision) zanieczyszczenie siarką sięgało, zależnie od receptury, $0,7-8 \%$ wag., fosforem $0,2-14 \%$ wag.

9 Zgodnie z recepturami z 1736 i 1790 r., które cytują Kirby i Saunders, “Fading.and Colour”, 83, 94, 95.

10 Kirby i Saunders, "Fading. and Colour", 82, 92, 97, 98.

11 Kirby i Saunders, "Fading.and Colour”, 76, 82, 92.

12 Receptura Dossie z 1758 r., dodatek kwasu w ostatnim etapie nie wystarczał do rozpuszczenia wodorotlenku glinu i usunięcia go. Receptura - Samain, "Degradation Mechanism", 253-254; Kirby i Saunders, "Fading.and Colour", 94. Rezultatem jest wysoki procent zanieczyszczenia końcowego produktu glinem.

13 André Béguin, Dictionnaire technique de la peinture, t. 1 A-B (Paris: MYG/Beguin 1978); Samain, "Degradation Mechanism", 24. 
mogły też być stosowane węglan lub siarczan wapnia, kaolin, czasem biel ołowiana. Dodatek taki - także białego pigmentu w charakterze wypełniacza - niekoniecznie oznaczał wyraźne rozjaśnienie. Czasem powodował większą transparentność, również w pełnym stężeniu pigmentu gotowego do użytku bądź farby, zwłaszcza przy uwarunkowanej procesem produkcji zawartości wodorotlenku glinu.

Od połowy XIX wieku zaczęła się masowa produkcja błękitu pruskiego z zastosowaniem całkowicie nieorganicznych surowców wyjściowych „metodami nowoczesnymi”, nazywanymi tak dla odróżnienia od wcześniejszych. Polegają one na reakcji między solami żelaza a kompleksem żelazocyjanowym, końcowy produkt - wytrącony pigment - można otrzymać w sposób bezpośredni lub pośredni ${ }^{14}$. Metody te są stosowane do obecnych czasów, w przemysłowej produkcji dominuje metoda pośrednia.

Współcześnie, gdy produkcja pigmentu przebiega z użyciem stechiometrycznych ilości nieorganicznych reagentów i w ściśle kontrolowanym procesie obwarowanym oficjalnymi patentami, uzyskiwane produkty są praktycznie pozbawione zanieczyszczeń. Badania przemysłowych błękitów pruskich wykazały zanieczyszczenie różnymi pierwiastkami nieprzekraczające łącznie $4 \%$ wagowych ${ }^{15}$.

Trzeba zaznaczyć, że chemicznie błękitu pruskiego nie określa - i nie określała także w przeszłości - tylko jedna formuła. Otrzymywany, w różnym stopniu uwodniony anion żelazocyjanowy żelaza ( $\left.\mathrm{Fe}^{\mathrm{III}}\left[\mathrm{Fe}^{\mathrm{II}}(\mathrm{CN}) 6\right] \cdot \mathrm{xH} 2 \mathrm{O}\right)$ ' może być połączony z kationem alkalicznym $\left(\mathrm{K}^{+}, \mathrm{NH}^{+}, \mathrm{Na}^{+}\right)$bądź posiadać „dodatkowe” kationy $\mathrm{Fe}^{\mathrm{III}}$, tworząc $\mathrm{Fe}^{\mathrm{III}}{ }_{4}\left[\mathrm{Fe}^{\mathrm{II}}(\mathrm{CN})_{6}\right]_{3}$. Błękit pruski zawierający któryś z wymienionych kationów alkalicznych jest nazywany „rozpuszczalnym”" ${ }^{16}$. Zarazem ostatnie zaawansowane badania budowy różnych błękitów pruskich tj. zawartości poszczególnych jonów, stopnia uwodnienia, niedoskonałości sieci krystalicznej - dowodzą, że struktura pigmentów określanych tym mianem nie odpowiada w sposób ścisły i jednolity strukturze określonej teoretycznie standardowymi wzorami stechiometrycznymi i strukturalnymi. Sposób pro-

14 W procesie pośrednim stosuje się sole trójwartościowego żelaza i sól zawierającą kompleks żelazocyjanowy żelaza dwuwartościowego (heksacyjanożealazinu) lub odwrotnie (w metodzie wyrobu błękitu Turnbulla): w procesie pośrednim używa się soli żelaza dwuwartościowego i w pierwszym etapie otrzymywana jest tzw. biel berlińska, utleniana następnie silnym utleniaczem do błękitu pruskiego.

15 Samain, "Degradation Mechanism", 55.

16 W istocie nie oznacza to rozpuszczalności (gdyż uzyskiwany jest nierozpuszczalny pigment, nie barwnik), lecz łatwość tworzenia koloidalnej zawiesiny w roztworach wodnych. 
dukcji wpływa na takie właściwości pigmentu, jak odcień, siła barwienia i siła krycia, zależne od parametrów optycznych warunkowanych wielkością otrzymanych cząsteczek i uporządkowaniem struktury. Odcień barwy „rozpuszczalnych” błękitów pruskich zależy także od charakterystycznych linii widmowych konkretnego jonu alkalicznego zawartego w ich strukturze. $Z$ tego powodu odmiany tego pigmentu zawierające kationy sodu mają odcień zielonkawy, a zawierające kationy amonowy lub potasowy - bardziej lub mniej czerwonawy ${ }^{17}$.

\section{Trwałość barwy błękitu pruskiego w warstwach malarskich - zastrzeżenia i rezultaty dotychczasowych badań}

Już wkrótce po jego odkryciu, wbrew pierwotnym opiniom, wyszło na jaw, że błękit pruski jest nietrwały w środowisku zasadowym, tym samym nie nadaje się do stosowania w technikach freskowych bądź w innych spoiwach o zasadowym odczynie ${ }^{18}$. Przeznaczony był głównie do malarstwa olejnego, akwareli i technik klejowych używanych w malarstwie dekoracyjnym. Już w ciągu XVIII wieku pojawiały się zastrzeżenia dotyczące trwałości jego barwy, uzasadniane argumentacją opartą na przekonaniu o jego organicznym charakterze i wsparte obserwacjami ${ }^{19}$. Stwierdzano zmianę odcienia na zielonkawy lub szarozielony w jaśniejszych tonach, tym wyraźniejszą, im jaśniejsza była odmiana pigmentu lub też wyjściowa barwa warstwy malarskiej - czyli w mieszaninach z bielą bądź w przejrzystych warstwach akwarelowych. Odnotowano też, już pod koniec XVIII i w następnym stuleciu, nieoczekiwaną zdolność do odzyskiwania barwy w ciemności przez cienkie warstwy wypłowiałe podczas ekspozycji w świetle słonecznym ${ }^{20}$.

Zastrzeżenia dotyczące trwałej zmiany barwy znajdują odzwierciedlenie w przykładach zidentyfikowanych w obrazach olejnych osiemnasto- i dziewiętnastowiecznych malarzy - Gainsborough, R. Wilsona, Tiepola, Watteau,

17 Louise Samain et al., "Relationship between the Synthesis of Prussian Blue Pigments, Their Color, Physical Properties, and Their Behavior in Paint Layers”, Journal of Physical Chemistry 117 (2013) 19: 9693, 9698-9712, doi: 10.1q021/jp3111327 (dostęp 7 lutego 2017).

18 W reakcji powstaje brązowy wodorotlenek żelaza i żółtawa żelazocyjankowa sól alkaliczna. Do odbarwienia wystarczy kontakt z powierzchnią o zasadowym pH pigmentu w innym spoiwie - zob. David Saunders i Jo Kirby, „The Effect of Relative Humidity on Artist's Pigments”, National Gallery Technical Bulletin 25 (2004): 63, http://www.nationalgallery.org.uk/technical-bulletin/saunders_kirby2004 (dostęp: 7 października 2016).

19 Kirby, "Fading and Colour”, 64, 65.

20 Szerzej opisana w połowie XIX w., szeroko obserwowana w cyjanotypiach oraz warstwach akwarelowych. 
Canaletta, Philippa Otto Rungego, a także w polichromii rzeźby anioła z La Gleize $^{21}$. Zapewne takich zmian, zważywszy popularność błękitu pruskiego na paletach malarzy, jest znacznie więcej. Ponieważ zachodzą one dość jednorodnie, uznawany za właściwy szarawy lub zielonkawy odcień partii obrazów, które w intencji artysty miały być - i pierwotnie były - bardziej niebieskie i nasycone, jest właściwie interpretowany dopiero po wyjęciu obrazu z ramy, gdy odsłonięcie nieodbarwionego fragmentu, np. partii nieba, demaskuje zmiany. Doniesienia z epoki dotyczące uzyskiwania z czasem przez osiemnasto- i wczesnodziewiętnastowieczne warstwy malarskie zawierające błękit pruski zielonkawego albo szarawego odcienia znalazły w ostatnich latach precyzyjne naukowe wyjaśnienie ${ }^{22}$. Odpowiedzialny jest za nie proces produkcji przeprowadzany zgodnie z wczesnymi recepturami. Nadmiar witriolu - uwodnionego siarczanu żelaza (II), niewypłukanego odpowiednio szybko po wytrąceniu osadu pigmentu, powodował, wskutek utleniania, tworzenie w masie strąconego błękitu pruskiego nanocząsteczek oranżowego uwodnionego tlenowodorotlenku żelaza (III), ferrihydrytu, którego barwa przy blaknięciu błękitu pruskiego wyraźniej wpływa na odcień warstwy malarskiej.

Na niestabilność odcienia wczesnych produktów handlowych mogło mieć również znaczący wpływ płowienie dodawanych do nich czerwonych laków. O ile ostatnie wyjaśnienie może być adekwatne tylko w stosunku do części warstw malarskich - zawierających podbarwiany błękit pruski, o tyle poprzednie podkreśla utratę barwy (płowienie) samego błękitu pruskiego, czytelną zwłaszcza w tonach rozjaśnionych. Tendencja ta nie dotyczy wyłącznie błękitu pruskiego wytwarzanego zgodnie z dawnymi recepturami, stosowanymi do połowy XIX wieku, ale i powstającego według metod nowoczesnych, w tym produkowanego współcześnie pigmentu najwyższej jakości. Wielkość cząsteczki błękitu pruskiego, zdeterminowana przez metodę jego produkcji, ma istotne znaczenie dla trwałości jego barwy. Zawartość w produkcie finalnym małych cząstek skutkuje większą tendencją do płowienia pod wpływem światła z powodu większej powierzchni, na którą ono oddziałuje, niż w przypadku cząstek większych. Zarazem niedoskonałości struktury niedostatecznie skry-

${ }^{21}$ Zob. przypis 6; Bartoll i Bärbel, "Prussian Blue”, 88; Louise Samain et al., "Synthesis and Fading of Eighteenth-Century Prussian Blue Pigments: A Combined Study by Spectroscopic and Diffractive Techniques Using Laboratory and Synchrotron Radiation Sources", Journal of Synchrotron Radiation 20 (May 2013): 470. Przytoczone przykłady zmian w obrazach z National Gallery w Londynie, z zamku Charlottenburg w Berlinie, z Kunsthalle w Hamburgu nie są jedynymi, lecz nielicznymi, które zostały zbadane i opublikowane.

22 Samain et al., "Synthesis and Fading”, 460-473. 
stalizowanych pigmentów mają wpływ i na intensywność barwy, i na potencjalne oddziaływanie $\mathrm{z}$ otoczeniem ${ }^{23}$. Obecne opinie producentów farb i pigmentów do użytku artystycznego dotyczące światłotrwałości błękitu pruskiego lub zawierających go farb są satysfakcjonujące - najczęściej dają ocenę bardzo wysoką ${ }^{24}$. Jednak oceny oparte na testach wykonanych według ścisłych procedur przyznają wysoką światłotrwałość pigmentowi w pełnym tonie, to jest czystemu i „w masie”, ale już nie tonom zawierającym mniejsze jego stężenie ${ }^{25}$.

Obniżanie się światłotrwałości błękitu pruskiego wraz z rozcieńczeniem pigmentu w warstwie malarskiej znajduje eksperymentalne potwierdzenie. Dotychczas przeprowadzone badania dotyczące warstw malarskich zawierających pigmenty będące błękitem pruskim wykazały takie same tendencje zmiany barwy indukowane procesem przyspieszonego starzenia pod wpływem światła. Badania obejmowały zarówno warstwy z dawnymi „historycznymi” błękitami pruskimi oraz wyprodukowanymi w laboratorium zgodnie z dawnymi recepturami lub zsyntetyzowanymi według metod nowoczesnych, jak i ze współczesnymi produktami handlowymi zmieszanymi w różnych stężeniach $\mathrm{z}$ białymi pigmentami oraz $\mathrm{w}$ warstwach akwarelowych w pełnym tonie i w rozcieńczeniu ${ }^{26}$.Zarejestrowano praktycznie brak zmian w pełnym tonie i zmiany tym intensywniejsze, im bardziej warstwa malarska była rozjaśniona, to jest mniejsze było stężenie zawartego w niej błękitu pruskiego. Stwierdzono, że rodzaj wypełniacza - np. wodorotlenku glinu zawartego w jednej z odmian dawnego błękitu pruskiego, siarczanu baru dodanego w innym przypadku bądź też białego pigmentu - jest nieistotny z punktu widzenia kierunku zachodzącej zmiany barwy ${ }^{27}$. Jej ewolucja rozpatrywana w kategoriach barwometrycznych

23 Samain et al., "Relationship between”, 9710.; Samain et al., "Synthesis and Fading”, 465.

24 Zob. np. karty kolorów akwarel artystycznych Talensa lub Winsor \& Newton - http://www. winsornewton.com/row/shop/water-colour/professional-water-colour/professional-water-colour-prussian-blue-0-17-us-fl-oz-5ml-tube-0102538 (dostęp 10 października 2016), a także dane pigmentu błękit pruski oferowanego przez Maimeri - http://www.maimeri.it/ it/categorie/restauro-e-pigmenti/pigmenti-puri-artisti/blu-di-prussia-3524402.html (dostęp 7 października 2016) - oraz Kremer Pigmente, gdzie najwyższą ocenę światłotrwałości przypisano też tonom rozjaśnionym - http:/00/www.kremer-pigmente.com/en/pigments/ pigments-of-modern-age/prussian-blue-lux-45202.html (dostęp 7 października 2016).

25 Zob. Joseph A. Sistino, "Ferrocyanide Pigments, Iron Blue”, w Pigment Handbook, t. 1, red. Temple C. Patton (New York: A Wiley_Interscience Publication, 1973), 402. Aktualne oceny ASTM (American Society for Testing and Materials), dokonywane zgodnie z normą ASTM D4303-10, Standard Test Methods for Lightfastness of Colorants Used in Artists' Materials, zamieszczane w międzynardowym Colour Index.

${ }^{26}$ Kirby i Saunders, “Fading. and Colour”, 83-87; Samain, “Degradation Mechanism”, 133-143.

${ }_{27}$ Kirby i Saunders, “Fading. and Colour”, 85, 86. 
( $L^{*}$ - jasność, $a^{*}$ - czerwono-zieloność i b* - niebiesko-żółtość) była dla różnych mieszanin zawierających błękit pruski zasadniczo podobna. Warstwy jaśniały, stawały się bardziej żółte (czyli mniej niebieskie) i mniej zielone ${ }^{28}$, z wyjątkiem zawierających pigmenty współcześnie przemysłowo produkowane, które nie wykazywały tej ostatniej tendencji w tonie mało stężonym (w warstwach akwarelowych). Na tle warstw zwierających błękity wyprodukowane zgodnie z osiemnastowiecznymi recepturami wyróżniły się jedynie te, w których metoda produkcji spowodowała dużą zawartość ferrihydrytu. Jego oranżowa barwa zdeterminowała wyraźnie większą, w porównaniu z pozostałymi badanymi warstwami, dodatnią zmianę parametrów a* $\mathrm{i}$ b*, przy jednocześnie większym pojaśnieniu ${ }^{29}$. Nieistotny, jeśli chodzi o postęp zmiany barwy, okazał się typ błękitu pruskiego - rozpuszczalnego bądź nierozpuszczalnego, przy czym jednak w przypadku odmian rozpuszczalnych zarejestrowano większe zmiany $^{30}$. Na ostateczną wielkość zmiany wpływa także zawartość wypełniacza wytrącanego wraz z pigmentem podczas jego produkcji (w postaci wodorotlenku glinu albo siarczanu baru). Jest ona silniejsza niż warstw malarskich zawierających inne odmiany błękitu pruskiego (bez „wbudowanego” wypełniacza) i do tego samego stopnia rozjaśnionych dodatkiem bieli.

Na podstawie wstępnego eksperymentu stwierdzono, że rodzaj białego pigmentu użytego do rozjaśnienia błękitu - bieli ołowianej, tytanowej, cynkowej, barytowej - zdaje się nie mieć wpływu na wielkość zmiany zachodzącej pod wpływem starzenia w świetle ${ }^{31}$. Obserwacji tej nie potwierdziły jednak rezultaty innych badań, z bielą ołowianą, cynkową i tytanową rutylową zmieszanymi w tych samych proporcjach z błękitem (10:1, wag.). Warstwy z bielą tytanową rutylową zmieniły się w najmniejszym stopniu, a z cynkową najznaczniej, za co są odpowiedzialne jej właściwości fotokatalityczne i chemiczne. Wzmagają one degradację spoiwa (olejnego w badanych przypadkach) i powodują tworzenie z nim mydeł. Zasadowy charakter bieli ołowianej i cynkowej może mieć również wpływ na proces degradacji samego błękitu pruskiego ${ }^{32}$. Autorzy obu badań zgodnie nie przypisują rodzajowi substancji błonotwórczej obecnej w badanych warstwach znaczącego wpływu

\footnotetext{
28 Kirby i Saunders, "Fading. and Colour", 84.

29 Samain, "Degradation Mechanism”, 142-143; Samain et al., "Synthesis and Fading”, 470.

30 Kirby i Saunders, “Fading.and Colour”, 85, fig. 3; Samain, “Degradation Mechanism”, 138, rys. 3b, c, 139.

31 Kirby i Saunders, "Fading. and Colour”, 86.

32 Samain, “Degradation Mechanism”, 166, 170, 174.
} 
na intensywność płowienia błękitu pruskiego ${ }^{33}$. Zauważono jednak, że o ile zmiana w warstwie współczesnego błękitu pruskiego, której spoiwem jest olej lniany, stopniowo narasta w miarę postarzania, o tyle w warstwie z gumą arabską szybko osiąga ostateczny poziom. W obu relacjonowanych badaniach stwierdzono, że odwracalność procesu zmiany barwy błękitu pruskiego w tonach rozjaśnionych dodatkiem bieli oraz mało stężonych akwarelowych jest znikoma, zachodzi tyko $\mathrm{w}$ warstwach eksponowanych w świetle względnie krótko przed przechowywaniem w ciemności ${ }^{34}$. Dłuższa, powtarzana ekspozycja spowodowała nieodwracalne zmiany.

Chemiczna strona opisywanych tu - stopniowych i w końcu nieodwracalnych - widocznych zmian rozjaśnionych odcieni błękitu pruskiego polega na wieloetapowych, złożonych mechanizmach z obszaru elektrochemii i chemii kwantowej. Zarazem naukowe, oparte na badaniach eksperymentalnych i szeregu analiz potwierdzenie stawianych hipotez nie jest łatwe. Sprowadzając określenie ich istoty do prostych stwierdzeń trzeba wyjaśnić, że za niebieską barwę błękitu pruskiego odpowiada międzywalencyjny transfer ładunków, możliwy dzięki występowaniu w tym związku jonów żelaza w różnym stopniu utlenienia $\left(\mathrm{Fe}^{\mathrm{III}}\right.$ i Fe $\left.{ }^{\mathrm{II}}\right)$. Zaburzenie dróg tego transferu pomiędzy jonami - z powodu ich redukcji albo utlenienia, wymiany jonów metali lub reakcji podstawienia cząstek wody w miejsce jonów cyjanowych - powoduje zmianę właściwości barwnych, utratę niebieskiego odcienia, czyli inaczej ujmując: degradację błękitu pruskiego objawiającą się płowieniem ${ }^{35}$. Zgodnie $\mathrm{z}$ obecną wiedzą, reakcje utleniania i redukcji zachodzą z pewnością nie tylko w wyizolowanym pigmencie, ale także w warstwach zawierających błękit pruski, indukowane światłem i innymi czynnikami ${ }^{36}$.

33 Kirby i Saunders, “Fading.and Colour”, 86 (wstępny test z gumą arabską, olejem lnianym, spoiwem dyspersyjnym akrylowym Liquitex i temperą jajową, nie określono typu błękitu pruskiego); Samain, “Degradation Mechanism”, 140,141 (porównywano olej lniany, gumę arabską i kazeinę).

34 Kirby i Saunders, "Fading. and Colour”, 88; Samain, “Degradation Mechanism”, 139.

35 David Ellis et al., "Electrochromism in the Mixed - Valence Hexacyanides. 1. Voltametric and Spectral Studies of the Oxidation and Reduction of Thin Films of Prussian Blue", Journal of Physical Chemistry 85 (1981) 9: 1225-1231, doi: 10.1021/j50609a025 (dostęp 7 października 2016); Kingo Itaya et al., "Electrocchmistry of Prussian Blue, An in Situ Moesbauer Effect Measurement, Journal of Physical Chemistry 86 (1982) 13: 2415-2418, doi: 10.1021/ j100210a033 (dostęp: 7 października 2015).

36 Zwięzłe zbiorcze przedstawienie schematu reakcji: Kirby i Saund rs, "Fading.and Colour", 88, 89; Samain, “Degradation Mechanism”, 20-23, 30-32, 146-152, 171-175; Minori Taguchi et al., "Photocontrolled Magnetization of CdS-Modified Prussian Blue Nanoparticles", Journal of American Chemical Society 128 (2006) 33: 10980-10982, http://; nathan.instras. com/ResearchProposalDB/doc-123.pdf (dostęp: 1 marca 2016). 


\section{Założenia i cel podjętych badań}

Zestawione powyżej informacje stanowią obszerny komentarz do zaprezentowanych wcześniej spostrzeżeń. Dostarczają istotnych danych, głównie na temat zachowania warstw malarskich imitujących warstwy występujące w obiektach zabytkowych, zawierające historyczne odmiany błękitu pruskiego, choć z porównawczym odniesieniem do współczesnych pigmentów. Celem przedstawionych poniżej własnych badań nie jest dyskusja z dotychczasową interpretacją mechanizmów tych procesów, a próba odpowiedzi na kilka pytań, które na tle dotychczasowej wiedzy się zrodziły - i postawienie nowych, istotnych dla potencjalnych „użytkowników” błękitu pruskiego jako składnika palety.

Z przytoczonych informacji wynika wniosek dla praktyki malarstwa i konserwacji - tendencję do utraty barwy w tonie rozjaśnionym manifestują wszystkie odmiany błękitu pruskiego, ze współczesnymi włącznie, choć różna może być ich intensywność. Autorzy relacjonowanych badań analizowali warstwy zawierające wyłącznie błękit pruski i biały pigment bądź rozcieńczony błękit pruski naniesiony na białe podłoże (w akwareli) - co przynosi informacje na temat zachowania różnych stężeń pigmentu w środowisku silnie rozpraszającym światło. Nie wynika z nich bezpośrednio, czy wystąpi ta sama tendencja, gdy jego stężenie będzie obniżone, ale w mieszaninach z innymi pigmentami barwnymi. Z punktu widzenia malarza i konserwatora ma to znaczenie, gdyż błękit pruski, pigment o dużej sile barwienia - więc intensywny także w małych stężeniach - stwarza wiele możliwości wykorzystania na palecie, nie tylko w błękitnych tonacjach. Mimo zastrzeżeń pod jego adresem formułowanych już wkrótce po upowszechnieniu tego pigmentu, polecano go do tworzenia odcieni fioletowych i zielonych przez mieszanie z ówcześnie dostępnymi czerwieniami i żółcieniami ${ }^{37}$. Szczególnie piękne tony mógł tworzyć z laserunkowymi pigmentami organicznego pochodzenia, co niestety także ograniczało trwałość uzyskanych mieszanin ${ }^{38}$. Popularne stały się mieszaniny określane czasem wspólnym mianem „zielonych cy-

37 Encyclopédie Méthodique ou par ordre des matières orne des portraits de M.M. Diderot et d'Alembert, t. 1 Beaux-Arts (Paris-Liège: Panckoucke Charles-Joseph, Plomteux Clément, 1788), 337; Jean-Félix Watin, L'art du peintre, doreur et vernisseur (Paris: Grangé, Durand, 1776), 47-48, http://gallica.bnf.fr/ark:/12148/bpt6k841821/f80.item.zoom (dostęp 7 października 2016).

38 Niektóre zaczęły być dostępne jako gotowe produkty, np. rozpowszechniona w XIX w. zieleń Hookera, będąca mieszaniną z gumigutą. 
nobrów”, tworzone z żółcienią neapolitańską i nowymi, już dziewiętnastowiecznymi żółtymi pigmentami - żółcieniami kadmowymi, a wcześniej chromowymi (chromianami) ${ }^{39}$. W handlu oferowano gotowe mieszaniny z tym ostatnimi żółcieniami, o efektownych odcieniach, kryjące i tanie, choć ich stabilność szybko oceniono negatywnie, wiążąc ją z chromianowym komponentem (jego częściową redukcją). Zielenie tworzone z żółcieniami kadmowymi, ugrami i marsami, sjenami, już w XX wieku z jednej strony polecano ${ }^{40}$, $\mathrm{z}$ drugiej zaś ostrzegano przed ich nietrwałościąa1.

Uwagi dwudziestowiecznych autorów podręczników malarstwa lub konserwacji na temat ryzykownych zestawień współczesnych pigmentów, z osobna uważanych za stabilne, skłoniły do przeprowadzenia wstępnej pierwszej serii badań kilku takich mieszanin w warstwach akwarelowych poddanych krótkotrwałemu sztucznemu starzeniu. Badania te dotyczyły warstw malarskich imitujących układ, a w tonach rozjaśnionych także optymalny skład, jaki może wystąpić we współczesnych uzupełnieniach - były to warstwy zaizolowane werniksem, do rozjaśnienia zaś użyto bieli tytanowej o zredukowanych właściwościach fotokatalitycznych, to jest w odmianie rutylowej. Wyniki pomiarów oraz spostrzeżenia odnośnie do zielonych, a w tonach rozjaśnionych także do jasnobłękitnych zielonkawych warstw malarskich zawierających błękit pruski, dokonane w toku badań i po dłuższym czasie od ich zakończenia, skłoniły do kontynuacji testów tych samych mieszanin. Zastanawiająca okazała się większa intensywność zmian w warstwach nierozjaśnianych bielą, wyłączywszy warstwę złożoną z samego błękitu pruskiego, czyli takich, w których stężenie tego pigmentu obniżał dodatek pigmentów barwnych żółcieni kadmowej, sjeny naturalnej, zieleni chromowej szmaragdowej.

Prezentowany poniżej kolejny już etap badań miał na celu próbę ustalenia, jak trwałe są zmiany barwy, czy ich zachodzenie warunkuje obecność tych właśnie pigmentów, czy wpływ na ich powstawanie mogą mieć rodzaj

39 Hopliński, Farby, 165.

40 Hopliński, Farby, 165.

41 Aleksiej V. Vinner, Materiały živopisi (Moskva: Gosudarstvennoje izdatel'stvo Iskusstvo, 1954), 60; Vasilij V. Tjutjunnik, Materiały i technika živopisi (Moskva: Akademija chudožestv SSSR, 1962), 92; Dimitri J. Kiplik, Technika živopisi (Moskva: Iskusstvo, 1960), 996; Viktor V. Fiłatov, Restavracja nastiennoj masljanoj živopisi (Moskwa: Izobrazitel'noe Iskusstvo, 1995), 51; Bohuslav Slansky, Technika malarstwa, t. 1 Materiały do malarstwa i konserwacji (Warszawa: Arkady, 1960), 50; Piotr Rudniewski, Pigmenty i ich identyfikacja (Warszawa: ASP, 1995), 63. 
użytego spoiwa ${ }^{42}$, rozpraszanie światła w warstwie częściowo zależne od jej właściwości kryjących oraz od typu białego wypełniacza o różnej zdolności pochłaniania promieniowania $\mathrm{z}$ różnego zakresu widma. $\mathrm{W}$ odniesieniu do praktyki malarstwa i konserwacji malarstwa wznowienie badań służyło uzyskaniu informacji, czy stwierdzona wcześniej niestabilność barwy wymienionych zieleni zawierających błękit pruski i popularnie z nim mieszane pigmenty jest cechą, którą należy im jednoznacznie trwale przypisać, a tym samym ich unikać, czy też przez dobór innego spoiwa (np. w uzupełnieniach) można niekorzystne zmiany ograniczyć bądź wyeliminować.

\section{Metodyka badań}

Badania polegały na ocenie zmian próbek warstw malarskich zawierających błękit pruski, zachodzących w wyniku kilkuetapowego przyspieszonego starzenia pod wpływem światła, a następnie porównaniu tych zmian w obrębie badanego zestawu. Błękit pruski był niezmiennym komponentem warstw, zmiennymi były: drugi barwny pigment nadający uzyskanej mieszaninie zielony odcień, wypełniacz bądź pigment służący rozjaśnieniu tonu, zgodnie z zasadą obowiązującą przy ocenie śwatłotrwałości pigmentów, oraz substancja błonotwórcza (dwa rodzaje i werniks). Skład pierwiastkowy użytych materiałów zweryfikowano metodą fluorescencji rentgenowskiej. Zmiany barwy starzonych warstw oceniano wizualnie i na podstawie spektrofotometrycznych pomiarów barwy. Wygląd próbek po kolejnych etapach starzenia rejestrowano fotograficznie. Dla kilku warstw malarskich podjęto próbę porównania stanu komponentów warstw na podstawie widm pobranych z nich próbek uzyskanych w spektroskopii ramanowskiej i spektroskopii w podczerwieni.

\section{Materiał badawczy i przygotowanie próbek}

Składnikami warstw malarskich poddanych testom były materiały, które potencjalnie mogą zaleźć się w asortymencie stosowanym przez konserwatorów: pigmenty i wypełniacz (Kremer Pigmente, Ge) oraz akwarele serii Rembrandt (Royal Talens, $\mathrm{Nl}$ ); wybór wypełniacza zasugerowało stosowanie go

42 To kontynuacja wcześniejszych prób (zob. przyp. 2), wtedy badano (FTIR) oddzielnie mieszaniny wyżej wymienionych barwnych pigmentów, warstwy uzyskane z substancji błonotwórczych (gumy arabskiej i Paraloidu B-72) i warstwy malarskie poddane sztucznemu starzeniu (FTIR, XRD). 
jako dodatku w handlowych błękitach pruskich ${ }^{43}$. Według dostępnych danych składniki przedstawiają się następująco:

\begin{tabular}{|c|c|c|c|}
\hline Nazwa & Skład & $\mathrm{pH}$ & Światłotrwałość \\
\hline $\begin{array}{l}\text { Błękit paryski, } \\
45210\end{array}$ & $\begin{array}{l}\text { C.I.: PB } 27.7510 \text { - } \\
\text { heksacyjanożelazian(II) } \\
\text { żelazowo(III)-amonowy } \\
\text { („rozpuszczalny”) }\end{array}$ & $3-6$ & BWS:8,8,8 \\
\hline $\begin{array}{l}\text { Żółcień kadmowa, } \\
21620\end{array}$ & $\begin{array}{l}\text { C.I.: PY } 35.77205 \text { - żółcień } \\
\text { siarczek cynkowo-kadmowy }\end{array}$ & 7 & BWS:7,7,7 \\
\hline $\begin{array}{l}\text { Sjena naturalna, } \\
17050\end{array}$ & $\begin{array}{l}\text { C.I :PY } 43 ? \text { - ziemia sjena } \\
\text { naturalna }\end{array}$ & & BWS:8,8,8 \\
\hline $\begin{array}{l}\text { Zieleń szmaragdowa viridian, } \\
44250\end{array}$ & $\begin{array}{l}\text { C.I.: PG } 18.77289 \text { - uwodniony } \\
\text { tlenek chromu }\end{array}$ & 8 & jw. \\
\hline $\begin{array}{l}\text { Biel tytanowa (rutyl) } \\
46200\end{array}$ & $\begin{array}{l}\text { C.I.: PW6.77891- dwutlenek } \\
\text { tytanu rutyl }\end{array}$ & 7,2 & jw. \\
\hline $\begin{array}{l}\text { Kreda bolońska } \\
58100\end{array}$ & $\begin{array}{l}\text { mieszanina naturalnego } \\
\text { uwodnionego siarczanu } \\
\text { i węglanu wapnia }\end{array}$ & & - \\
\hline $\begin{array}{l}\text { Akwarela Prussian Blue, } \\
508\end{array}$ & $\begin{array}{l}\text { C.I.: PB27 - } \\
\text { heksacyjanożelazian(II) } \\
\text { żelazowy(III) (nieokreślony } \\
\text { „rozpuszczalny” lub nie), guma } \\
\text { arabska }\end{array}$ & & +++ \\
\hline $\begin{array}{l}\text { Akwarela Raw Sienna, } \\
234\end{array}$ & $\begin{array}{l}\text { C.I.: PY43 - naturalny } \\
\text { uwodniony tlenek żelaza, guma } \\
\text { arabska }\end{array}$ & & +++ \\
\hline $\begin{array}{l}\text { Akwarela Cadmium Yellow Light, } \\
208\end{array}$ & $\begin{array}{l}\text { C.I.: PY35 - siarczek cynkowo- } \\
\text { kadmowy, guma arabska }\end{array}$ & & +++ \\
\hline $\begin{array}{l}\text { Akwarela Vert émeraude, } \\
616\end{array}$ & $\begin{array}{l}\text { C.I.: PG18 - uwodniony tlenek } \\
\text { chromu, guma arabska }\end{array}$ & & +++ \\
\hline
\end{tabular}

(+++ i BWS (Blue Wool Standard) 8,8,8 są oznaczeniami najwyższej światłotrwałości)

43 Capucine Korenberg, "The Photo-Ageing Behaviour of Selected Watercolour Paints Under Anoxic Conditions”, The British Museum Technical Research Bulletin 2 (2004): 51. 
Jako spoiwa użyto wodnego roztworu gumy arabskiej (Talens Gum Arabic 008, Royal Talens, Nl) oraz 10-procentowego roztworu Paraloidu B-72 (Rohm \& Haas, USA) w acetonie, rozcieńczalnikami były odpowiednio woda destylowana i aceton.

Skład pierwiastkowy pigmentów, farb i gumy arabskiej zanalizowany metodą spektroskopii fluorescencji rentgenowskiej zasadniczo odpowiadał składnikom deklarowanym przez producentów. W kilku produktach wskazywał na domieszki. W przypadku akwarel „błękit pruski” zawierał dodatkowo najprawdopodobniej siarczan wapnia, „sjena” - biel tytanową, a akwarela i pigment „zieleń szmaragdowa” - węglan wapnia ${ }^{44}$. Guma arabska zawarta w akwarelach i gotowym spoiwie jest solą wapniową i potasową (kwasu arabinowego).

Na wstępie przygotowano mieszaniny pigmentów, łącząc żółcień kadmową, sjenę naturalną bądź zieleń szmaragdową z błękitem pruskim w stosunku wagowym 5: 1. Część uzyskanych mieszanin połączono z bielą tytanową w proporcji: 1 część barwnej mieszaniny do 10 części bieli (wag.), a drugą część z kredą bolońską w proporcji 1:100 w celu uzyskania widocznego, podobnego w obu wypadkach rozjaśnienia ich barwy ${ }^{45}$. Następnie po połączeniu ze spoiwami naniesiono je na odtłuszczone płytki szklane. Warstwy akwarelowe wykonano dostosowując odcień mieszanin i stopień rozjaśnienia do uzyskanych z mieszanin pigmentów. Dodawany wypełniacz oraz biel tytanową uprzednio łączono z roztworem gumy arabskiej.

Próbki uzyskanych cienkich warstw malarskich przed poddaniem ich przyspieszonemu starzeniu wysezonowano w temperaturze pokojowej i wilgotności względnej 30-40\% przez dwa tygodnie. W późniejszym czasie około jednej trzeciej przeznaczonej do ekspozycji powierzchni większości próbek warstw malarskich pokryto werniksem akrylowym (Talens Acrylic Varnish Glossy114) i ponownie sezonowano w tych samych warunkach przez miesiąc.

44 Analizy XRF na spektrometrze rentgenowskim Philips MiniPal 4025 z układem helowym wykonał Adam Cupa w Zakładzie Technologii i Technik Malarskich UMK w 2015 r.

45 Oznacza to różne w obu wypadkach proporcje błękitu pruskiego do traktowanych łącznie pozostałych składników mieszanin; odpowiednio: błękit pruski z bielą tytanową: 9\%, w mieszaninie z innymi pigmentami i bielą tytanową: 1,5\%; błękit pruski z kredą bolońską: $1 \%$, w mieszaninie $\mathrm{z}$ innymi pigmentami i kredą bolońską: $0,16 \%$. 


\section{Przyspieszone starzenie pod wpływem światła}

Starzenie próbek warstw malarskich przeprowadzono w świetle lampy ksenonowej (Xenotest Aplha HE, Atlas, USA), przy natężeniu napromienienia $\mathrm{E}=40 \mathrm{~W} / \mathrm{m}^{2}$ dla $\lambda=320-400 \mathrm{~nm}$. Warunki napromieniania imitowały warunki wewnątrz pomieszczeń, przy wilgotności względnej utrzymywanej na poziomie $40 \%$ i temperaturze nieprzekraczającej $43^{\circ} \mathrm{C}$ na powierzchni próbki. Jednocześnie z próbkami starzono niebieskie wzorce (ISO 105). Starzenie warstw malarskich prowadzono w kilku etapach, stopniowo odsłaniając i przesłaniając fragmenty eksponowanej powierzchni, przerywając cykl i przechowując próbki w ciemności w celu zaobserwowana i rejestracji ewentualnego cofania się zmian. Po identycznych krótkich etapach starzenia przerwy wynosiły dziesięć dni, miesiąc (okres sezonowana paska zawerniksowanego), pięć dni, dwa miesiące, po czym nastąpiły dwa dłuższe etapy starzenia. Wszystkie kolejno eksponowane fragmenty postarzanej powierzchni próbek otrzymały identyczną łączną dawkę napromienienia $49562 \mathrm{~kJ} / \mathrm{m}^{2}$ (mierzoną w zakresie 320-400 nm), co odpowiadało osiągnięciu zmiany w stopniu 4 na wzorcu BWS nr 6. Ponieważ celem badania nie było określenie światłoodporności najodporniejszych próbek, a porównanie zarejestrowanych zmian w obrębie badanego zestawu, na tym etapie badanie zakończono, zakładając możliwość kontynuacji w przyszłości.

\section{Rejestracja i ocena zmian}

Zmiany barwy po każdym etapie starzenia oceniano wizualnie i rejestrowano fotograficznie. Pomiary barwy wykonywano krótko po pochłonięciu identycznych kolejnych dawek napromienienia przez sekwencyjnie postarzane fragmenty warstw (bez izolacji i zaizolowane werniksem). Kontrolnie wykonano dwa pomiary po trzydziestu sześciu i siedemdziesięciu ośmiu dniach przechowywania w ciemności, rejestrując wygląd próbek na tych etapach również fotograficznie. Pomiary barwometryczne wykonano spektrofotometrem odbiciowym sferycznym (SP-64, X-Rite USA) z włączoną składową zwierciadlaną (SCI) w celu oceny rzeczywistej barwy, a nie wyglądu próbki, na który mają wpływ nieregularności jej powierzchni ${ }^{46}$. Pomiarów dokonywano w oznaczo-

46 Geometria pomiarowa $\mathrm{d} / 8^{\circ}$, illuminant CIE D65, obserwator standardowy normalny $10^{\circ}$, spektrum 400-700 nm. Opis barwometrycznej oceny warstw malarskich zob. Elżbieta Szmit-Naud, „Wrażenie barwy i klasyfikacja barw. Ocena zmian barwy materiałów stosowanych 
nych (tych samych) strefach próbki. Zmiany barwy oceniano według wzoru $\Delta \mathrm{E}_{00}$ (DE 2000), gdzie dla współczynników $\mathrm{k}_{\mathrm{L}}, \mathrm{k}_{\mathrm{C}}, \mathrm{k}_{\mathrm{H}}$ przyjęto wartość 1 . Analizowano też odrębnie krzywe odbicia starzonych warstw i zmiany wartości $\mathrm{L}^{*}, \mathrm{a}^{*}, \mathrm{~b}^{*}$ oraz $\mathrm{h}^{*}$, by określić kierunek zmian barwy.

Podjęto próbę prześledzenia zmian składników warstw malarskich, przede wszystkim błękitu pruskiego, wykonując pomiary w spektroskopii ramanowskiej laserem 785 nm (spektroskop Raman Perkin Elmer Raman Micro 200) oraz dokonując analizy absorpcyjnej w podczerwieni w zakresie 400-4000 $\mathrm{cm}^{-1}$ (spektrofotometr Genesis II, Mattson, USA, z oprogramowaniem WinFirst) dla kilku wybranych próbek ${ }^{47}$.

\section{Rezultaty przeprowadzonych badań}

Już po pierwszym etapie starzenia warstw nieizolowanych werniksem na eksponowanych powierzchniach odnotowano bardzo wyraźne zmiany barwy próbek. Najsilniejsze wystąpiły na próbkach wykonanych akwarelami Rembrandt, zwłaszcza w tonach przejrzystych (bez białych dodatków) oraz rozjaśnianych dodatkiem kredy bolońskiej ( $\mathrm{dE}_{00}$ od 9,27 aż do 25,95), w mniejszym stopniu w warstwach rozjaśnionych dodatkiem bieli tytanowej $\left(\mathrm{dE}_{00}\right.$ $4,88 ; 7,61 ; 8,15)$. Podobnie, choć mniej intensywnie przedstawiały się zmiany warstw uzyskanych przez zmieszanie pigmentów z gumą arabską. Tu silniejsze zmiany zaszły w warstwach rozjaśnionych i w mieszaninach z żółcienią kadmową oraz sjeną były większe z bielą tytanową. Barwa warstwy błękitu pruskiego z gumą arabską w pełnym tonie pozostała wizualnie bez zmian (w pomiarach $\mathrm{dE}_{00}=3,68$, to skutek zmatowienia powierzchni), w tonach rozjaśnionych zmiany były wyraźnie czytelne bądź znaczne $\left(\mathrm{dE}_{00}=4,89 \mathrm{z} \mathrm{TiO}_{2}\right.$ i 13,99 z kredą bolońską) (il. 1). W warstwach zawierających te same mieszaniny pigmentów, ale ze spoiwem z Paraloidu B-72 wyraźna zmiana dotyczyła mieszaniny z samą kredą bolońską, ledwo dostrzegalnie zmieniła się mieszanina z tym wypełniaczem i ze sjeną naturalną $\left(\mathrm{dE}_{00}=1,89\right)$. Fragmenty pokryte izolacją werniksową $\mathrm{w}$ porównaniu $\mathrm{z}$ nieizolowanymi poddanymi napromienianiu o tej samej dawce wykazały te same tendencje, widoczne do-

w konserwacji dzieł sztuki”, Acta Universitatis Nicolai Copernici. Zabytkoznawstwo i Konserwatorstwo 43 (2005): 55-63.

47 Pomiary metodą spektroskopii ramanowskiej wykonała Jolanta Wółkiewicz w Pracowni Analiz Instrumentalnych a analizę absorpcyjną w IR wykonała Marta Chylińska w Katedrze Chemii i Fotochemii Polimerów Wydziału Chemii UMK. 
brze w warstwach $\mathrm{z}$ akwarelą. W ewaluacji dokonanej po przeprowadzonym kolejnym etapie starzenia stwierdzono utrzymywanie się i wzrost zaobserwowanych tendencji zmian barwy w eksponowanym polu, mimo uprzedniego cofnięcia się zmian, w różnym stopniu, w strefach nieeksponowanych i podczas przechowywania w ciemności. Po dłuższej przerwie (78 dni) i przechowywaniu bez dostępu światła zmiany barwy w strefach starzonych zmalały (il. 2). W warstwach z gumą arabską (akwarelowych i pozostałych) w strefach zaizolowanych werniksem w porównaniu z niewerniksowanymi „cofanie się” zmian często było mniejsze. Kolejne cykle napromieniania spowodowały jednak ponowny wzrost zmian, często do wartości bliskich osiągniętym po pierwszym etapie starzenia $\mathrm{w}$ warstwach nieizolowanych rozjaśnianych dodatkiem wypełniacza, a poniżej tych wartości w warstwach rozjaśnionych bielą tytanową (il. 3). Nadal najintensywniejsze zmiany rejestrowano w warstwach malarskich zawierających gumę arabską (akwarelowe i uzyskane przez mieszanie pigmentów z roztworem gumy) (il. 3, 4). W nierozjaśnianych warstwach z gumą arabską zmiany były niższe lub zbliżone do osiągniętych po pierwszym etapie starzenia w warstwach niewerniksowanych, a w werniksowanych - bliskie wówczas osiągniętym. Natomiast w warstwach rozjaśnianych pokrytych werniksem nastąpił znaczny wzrost zmian barwy, w przeciwieństwie do warstw bez izolacji. Na próbkach z akwarelami bardzo wyraźne pogłębienie zmian wystąpiło we wszystkich warstwach rozjaśnianych dodatkiem kredy bolońskiej (il. 4). Ostatecznie, zmiany barwy tonów rozjaśnionych przez dodatek wypełniacza niemal we wszystkich przypadkach były większe niż przy użyciu bieli tytanowej.

We wszystkich warstwach z Paraloidem B-72 w pomiarach odnotowano większe zmiany niż powstałe po pierwszym etapie starzenia, niemniej jednak nadal na poziomie wzrokowo niezauważanym (il. 4, 5).

W ocenie barwometrycznej warstwy malarskie z samego błękitu pruskiego wykazały większe zmiany barwy niż nierozjaśnione zielone mieszaniny tego pigmentu (z żółcienią kadmową, sjeną naturalną, zielenią szmaragdową). Zmiany rozjaśnionych warstw błękitu pruskiego zachodziły z podobną lub większą intensywnością w porównaniu z jego zielonymi mieszaninami $\mathrm{w}$ tych samych spoiwach ${ }^{48}$. Wizualnie słabsze zmiany barwy warstw, w których błękit pruski jest zmieszany z zielenią chromową (szmaragdową), w oce-

48 Bezpośrednich odniesień i porównań nie pozwala dokonywać różna zawartość tego pimentu w omawianych warstwach. 
nie barwometrycznej okazują się porównywalne ze zmianami pozostałych mieszanin. Nie można jednoznacznie wskazać, który z trzech typów zielonych mieszanin z błękitem pruskim wykazuje silniejszą skłonność do zmian pod wpływem światła.

Wspólną tendencję zmian barwy we wszystkich badanych warstwach malarskich można najogólniej określić jako wzrost jasności L* i obniżenie kąta odcienia h* (co oznacza ewolucję tonów wyjściowo zielononiebieskich w kierunku bardziej zielonych, a zielonych w kierunku żółtawych).

Podjętych wstępnie prób analizy zmian będących rezultatem transferu elektronów, to jest zachodzenia redukcji i utleniania błękitu pruskiego, na podstawie widm spektroskopii w podczerwieni (ATR FTIR) i ramanowskiej nie można uznać za wystarczające ani całkowicie udane. Z próbek rozjaśnionych prezentujących intensywne zmiany barwy, ale zawierających niskie stężenie błękitu pruskiego (poniżej 1,5\%) nie uzyskano widm nadających się do interpretacji. W kilku próbkach zawierających błękit pruski w większym stężeniu widoczne są, następujące podczas starzenia, zmiany w obszarze drgań rozciągających CN-kompleksów żelazocyjanowych związanych z żelazem na różnym stopniu utlenienia. Można, posiłkując się interpretacjami zawartymi w literaturze ${ }^{49}$, uznać je za symptomy procesów utleniania i redukcji błękitu pruskiego, co jednak nie pozwala na sformułowanie dalej idących ogólnych wniosków (il. 6, 7).

\section{Próba interpretacji wyników badań}

Na obecnym etapie badań nie było wprawdzie możliwe pełniejsze instrumentalne prześledzenie chemicznych mechanizmów zmian, jakim podległy badane warstwy malarskie, lecz dotychczasowa wiedza i uzyskane wyniki skłaniają do wysnucia kilku wniosków i postawienia hipotez.

Światło nie wydaje się jedynym czynnikiem uruchamiającym reakcje przemian błękitu pruskiego. Prawdopodobne jest, że składniki poddawanych przyspieszonemu starzeniu warstw malarskich mogą wzajemnie stymulować swój rozkład. W badanych mieszaninach może mieć znaczenie elektrochemiczne podłoże zmian, wynikające z półprzewodnikowego zachowania wszystkich trzech barwnych pigmentów: błękitu pruskiego, siarczku kadmu

49 Taguchi et al., "Photocontrolled Magnetization”, 10979, 10980; Samain, “Degradation Mechanism”, 144, 150-152, 161, 164, 168-170. 
i tlenku chromu ${ }^{50}$. Eksperymentalnie potwierdzony transfer elektronów w przypadku nanocząsteczek siarczku kadmu i błękitu pruskiego skłania do postawienia takiej hipotezy ${ }^{51}$.

Istotnym rezultatem przeprowadzonych badań starzeniowych jest stwierdzenie niezachodzenia wyraźnych zmian w warstwach zawierających mieszaniny barwnych pigmentów ze spoiwem z Paraloidu B-72 w porównaniu z tymi mieszaninami w warstwach z gumą arabską (z akwarel bądź roztworu). Wskazuje to, że światło i sama obecność jonów kadmowych i cynkowych (z CdS·ZnS, PY 37), żelazowych (z uwodnionego tlenku żelaza w sjenie), chromowych nie były czynnikami jedynymi i wystarczającymi, by uruchomić na większą skalę reakcje prowadzące do zmian barwy (il. 2, 4, 8). Z kolei ich generalnie znacznie większa intensywność w warstwach zawierających gumę arabską każe przypuszczać, że zastosowanie jej roztworu jako spoiwa miało dla zachodzenia zmian barwy istotne znaczenie. Higroskopijne środowisko tych warstw malarskich może tworzyć wystarczające warunki dla transferu elektronów między obecnymi w nich półprzewodnikowymi pigmentami, czyli zachodzenia reakcji ich utleniania i redukcji błękitu ${ }^{52}$. Poza tym zmiany barwy błękitu pruskiego związane z procesem jego utleniania mogą być związane ze zdolnością przyłączania cząstek wody w miejscach defektów jego struktury, aniony $\mathrm{OH}^{-}$dostarczane $\mathrm{z}$ wodnym rozcieńczalnikiem (gumy) mogą teoretycznie utlenić jony żelaza Fe ${ }^{\mathrm{II}}{ }^{53}$ Wydaje się też, że obecność gumy arabskiej w badanych warstwach może mieć znaczenie dla zachodzących zmian barwy; badania tej substancji w obecności jonów żelaza ${ }^{\text {II }}$ potwierdziły jej szybki rozkład w warunkach sztucznego starzenia ${ }^{54}$.

50 Willemien Anaf et al., "Understanding the (In)Stability of Semiconductor Pigments by a Thermodynamic Approach", Dyes and Pigments 113 (2015): 409-415.

51 Analitycznie potwierdzono indukowany przez światło transfer elektronów z CdS do błękitu pruskiego i wynikającą z niego redukcję $\mathrm{Fe}^{\mathrm{III}}-\mathrm{CN}-\mathrm{Fe}^{\mathrm{II}}$ do $\mathrm{Fe}^{\mathrm{II}}-\mathrm{CN}-\mathrm{Fe}^{\mathrm{II}}$; Taguchi et al, "Photocontrolled Magnetization”, 10980-10981.

52 Pigmenty takie jak CdS, $\mathrm{ZnS}, \mathrm{Cr}_{2} \mathrm{O}_{3}$ w warunkach podwyższonej wilgotności, powstających w higroskopijnym środowisku, są podatne na utlenianie; Anaf et al., "Understanding the (In) Stability", 412, 414.

53 Do anionu $\left[\mathrm{Fe}^{\mathrm{III}}(\mathrm{CN})_{5} \mathrm{OH}\right]^{-3}$, zgodnie z wynikami badań procesów elektrochemicznych w błękicie pruskim syntetzowanym elektrochemicznie; zob. np. Jeronimo Agrisuelas et al., "Electronic Perspective on the Electrochemistry of Prussian Blue Films", Journal of The Electrochemical Society 156 (2009) 4: 74-80.

54 Badania GC-MS samej gumy i zmieszanej na sucho z $\mathrm{FeSO}_{4}$, postarzonej $\mathrm{w} \mathrm{T}=90^{\circ} \mathrm{C}$ i RH od 35 do $80 \%$ wykazały brak zmian wyizolowanej gumy, natomiast jej rozkład w mieszaninie; Véronique Rouchon Quillet et al., "The Impact of Gum Arabic on Iron Gall ink Corrosion", Restaurator 25 (2004) 4: 220-232, www.viks.sk/chk/dpw23.doc (dostęp 7 października 2016). 
W związku z tym wyraźne zmiany powstałe także w zielonych warstwach, w których błękit pruski został zmieszany ze sjeną naturalną, skłaniają do przypuszczenia, że ten składnik ma wpływ na zmiany barwy mieszaniny nie tylko dlatego, że wskutek odbarwiania błękitu pruskiego jego barwa zaczyna dominować, ${ }^{55}$ ale być może także ze względu na to, że stymuluje zmiany gumy arabskiej. Wydaje się prawdopodobne, że składniki poddawanych przyspieszonemu starzeniu warstw malarskich mogą wzajemnie wpływać na swoją degradację. Potwierdzenie tych hipotez na drodze analitycznej wymaga odrębnego programu badawczego, z włączeniem innych niż zastosowane metod instrumentalnych.

Zestawienie rezultatów pomiarów badanych warstw pozwala zauważyć, że zawartość spoiwa z gumy arabskiej w warstwach malarskich z błękitem pruskim ma wpływ na zachodzenie zmian ich barwy pod wpływem światła. Intensywniejsze zmiany w warstwach otrzymanych z farb akwarelowych (też zawierających gumę arabską) należy przypuszczalnie wiązać ze znacznie lepszym i większym zdyspergowaniem w nich cząstek pigmentów i mniejszą siłą krycia, więc zarazem z silniejszym rozpraszaniem w nich światła w porównaniu z warstwami utworzonymi przez zmieszanie pigmentów ze spoiwem, gorzej zdyspergowanymi i bardziej kryjącymi.

Odrębną kwestią jest wpływ białego wypełniacza bądź pigmentu dodawanego w celu rozjaśnienia barwy warstw. Analizując zachowanie warstw rozjaśnionych nie można dokonywać bezpośrednich porównań między nimi z powodu różnic proporcji błękitu pruskiego (i pozostałych barwnych pigmentów) do pigmentu bądź wypełniacza w warstwach w podobnym stopniu rozjaśnionych ${ }^{56}$, co jest spowodowane odmienną charakterystyką widmową tych dodatków, czyli ich zdolnością rozjaśniana. Zbliżone proporcje błękitu występują w mieszaninie samego błękitu z bielą tytanową i w zielonych mieszaninach z kredą bolońską. Przebieg ich starzenia wskazuje na zachodzenie

Mechanizmy prowadzące do tych zmian nie były przez autorów analizowane. Wcześniejsze badania autorki (zob. przypis 2 i 41) warstw samych substancji błonotwórczych oraz warstw malarskich i próby porównań widm nie pozwoliły na wyciagnięcie konstruktywnych wniosków dotyczqcych zmian w spoiwach.

55 Samain, “Degradation Mechanism”, 143, 183; Samain et al., „Synthesis and Fading”, 460, 473 - sugestia dotycząca warstw zawierających ferrihydryt, będący tlenowodorotlenkiem żelaza, podobnie jak główny komponent sjeny. Autorka zamyka interpretację stwierdzeniem, że blaknięcie błękitu pruskiego powoduje dominowanie jego barwy, jednocześnie zauważając, że warstwy z gumą arabską, które go zawierały, wyblakły bardziej, podobnie jak zmieszane z wypełniaczem; Samain, “Degradation Mechanism”, 136, 143.

56 Zob. przypis 44. 
wyraźniejszych zmian w warstwach z wypełniaczem (il. 9), chociaż to biel tytanowa, pigment o bardzo małej cząsteczce, intensywniej rozprasza światło w warstwie. Logicznym wyjaśnieniem wydaje się ekranujące działanie bieli tytanowej, silnie absorbującej w paśmie bliskiego ultrafioletu (a zarazem, w zastosowanej odmianie, mającej zredukowane właściwości fotokatalityczne), podczas gdy wypełniacz nie wykazuje takiego osłaniającego działania. Warto zarazem zaznaczyć, że w poddanych przyspieszonemu starzeniu warstwach rozjaśnionego bielą tytanową błękitu pruskiego występował on w granicznym stężeniu ${ }^{57}$, poniżej którego jego odporność wyraźnie spada. Tłumaczy to też wyraźne zmiany barwy rozjaśnionych nim mieszanin z gumą arabską, gdzie występował w stężeniu 1,5\%. Niemniej jednak to samo stężenie nie stało się powodem istotnych zmian barwy warstw o identycznym składzie w spoiwie akrylowym. Ta obserwacja przemawia za wyżej wyrażonym przypuszczeniem, że na zachodzenie reakcji prowadzących do zmian barwy warstw malarskich zawierających błękit pruski miał wyraźny wpływ - oprócz światła - rodzaj spoiwa, w badanych próbkach - roztwór gumy arabskiej, rzutując tym samym na ich intensywność. Otrzymane rezultaty każą więc nie zgodzić się z cytowaną wcześniej opinią co do braku wpływu rodzaju spoiwa i wypełniacza (bieli) na intensywność zmian ${ }^{58}$.

Istotna informacja - z konserwatorskiej perspektywy - wynika ze spostrzeżeń dotyczących izolacji badanych warstw werniksem (tu akrylowym, polimetakrylanem izobutylu). Analiza danych barwometrycznych pozwala stwierdzić, że werniksowanie nie działa hamująco na powstawanie zmian barwy w warstwach pod wpływem światła, natomiast ogranicza - w porównaniu z warstwami nieizolowanymi - ich cofanie się podczas przechowywania w ciemności. Można to wyjaśnić tworzeniem przez błonę werniksu bariery ograniczającej dyfuzję do warstwy malarskiej tlenu, powodującego ponowne utlenienie błękitu pruskiego, który wcześniej uległ redukcji. Najprawdopodobniej ta właśnie przyczyna skutkuje też końcowymi, najczęściej odnotowywanymi, większymi zmianami barwy warstw izolowanych werniksem w porównaniu z identycznymi nieizolowanymi. W znikomym stopniu wpływać na nie mogą zmiany barwy samego werniksu. Wskazuje na to zarówno charakter zmian określany parametrami barwy, jak i samo wizualne porównanie zmienionych zaizolowanych warstw (il. 2, 3, 9).

57 Kirby i Saunders, “Fading.and Colour”, 75, 90.

58 Kirby i Saunders, "Fading and Colour”, 86. 
Zaobserwowane podczas badań „cofanie się” zmian po dłuższym okresie przechowywania w ciemności nie pozwala wyrokować o osiągnięciu ich ostatecznego, trwałego poziomu na obecnym etapie przyspieszonego starzenia, zwłaszcza w nieizolowanych warstwach malarskich rozjaśnionych bielą tytanową i zawierających gumę arabską jako spoiwo (il. 3). W przyszłości możliwa będzie dalsza ocena.

\section{Wnioski końcowe}

Przedstawiony w artykule materiał nie wyczerpuje podjętej problematyki badawczej. Planowana pełniejsza naukowa charakterystyka mechanizmów odnotowanych zmian barwy w testowanych warstwach malarskich, z określeniem typu przemian błękitu pruskiego i jego oddziaływań z innymi składnikami tych warstw, wymaga szerokiego programu badawczego zakładającego użycie szeregu metod analitycznych - między innymi, prócz zastosowanych technik wibracyjnych, wysoko wyspecjalizowanych metod spektroskopowych i z zakresu elektrochemii. Wnosząc wartości poznawcze, umożliwi także ewentualne ograniczenie lub eliminowanie zmian warstw malarskich, zwłaszcza w praktyce konserwacji i restauracji dzieł sztuki.

Niemniej jednak już w chwili obecnej, z pełną świadomością ograniczeń przeprowadzonych badań, na podstawie dotychczas uzyskanych rezultatów można wysnuć kilka praktycznych wniosków. Wprawdzie zielone i błękitnozielone mieszaniny z błękitem pruskim ze względu na ich właściwości barwne wciąż mogą być uważane za atrakcyjny składnik palety, należy wszakże podkreślić, że mieszanin błękitu pruskiego z żółcienią kadmową, sjeną naturalną (prawdopodobnie też z ugrem i marsami) nie można uznać za niezmienne podczas ekspozycji w świetle. Zakres zmian jest uzależniony od stężenia błękitu pruskiego w warstwie i można się spodziewać, że również w tonach uzyskiwanych bez dodatku bieli, ale z większą ilością tych żółtych pigmentów, niż zastosowana w badaniach, nastąpią intensywniejsze zmiany. W odcieniach zbliżonych do badanych (czyli w podobnych stężeniach) można bez ryzyka zauważalnych zmian stosować je w uzupełnieniach z Paraloidem B-72 (il. 8), chociaż nie oznacza to absolutnej niezmienności takich mieszanin. Nie należy jednak przewidywać, opierając się na pozytywnych rezultatach użycia tego rozpuszczalnikowego spoiwa akrylowego, podobnego zachowania przy zastosowaniu innych substancji błonotwórczych, także 
żywicznych, w tym akrylowych, zwłaszcza rozcieńczanych wodą ${ }^{59}$. Analiza zarejestrowanych zmian barwy warstw malarskich skłania do tego, by odradzić stosowanie badanych mieszanin w technice akwareli, a w praktyce konserwatorskiej - w akwarelowych werniksowanych uzupełnieniach, gdyż nawet zakładając częściową odwracalność procesu, nie można oczekiwać w tym przypadku powrotu do pierwotnego wyglądu. Mniej drastycznych, ale zauważalnych zmian podczas ekspozycji w świetle należy się spodziewać $\mathrm{w}$ tych barwnych mieszaninach z bielą tytanową rutylową. Znacznie silniejsze zmiany może wywołać w nich dodatek wypełniaczy - np. w malarstwie w technice gwaszowej, w konserwatorskich uzupełnieniach z użyciem gwaszu czy modyfikowanej nim akwareli -bądź dodatek innych białych pigmentów, świadomie pominiętych w badaniach ze względu na ich aktywność fotokatalityczną lub chemiczną.

\section{Bibliografia}

\section{Druki i opracowania}

Agrisuelas, Jerónimo, Paulo R. Bueno, Fabio F. Ferreira, Claude Gabrielli, José García-Jareño, David Gimenez-Romero, Hubert Perrot, i Francisco Vicente. "Electronic Perspective on the Electrochemistry of Prussian Blue Films". Journal of The Electrochemical Society 156 (2009) 4: 74-80.

Anaf, Willemien, Olivier Schalm, Koen Janssens, i Karolien De Wael. "Understanding the (In)Stability of Semiconductor pigments by a thermodynamic Approach". Dyes and Pigments 113 (2015): 409-415.

Asai, Chiharu. "Handmade Berlinerblau". Zeitschrift für Kunsttechnologie und Konservierung 18 (2005) 2: 261-292.

Bartoll, Jens, i Jackisch Bärbel. "Prussian Blue. A Chronology of the Early Years". Zeitschrift für Kunsttechnologie und Konservierung 24 (2010) 1: 88-102.

Béguin, André. Dictionnaire technique de la peinture. T. 1 A-B. Paris: MYG/Beguin, 1978. Bomford, David, i Ashok Roy. “Canaletto' Stonemason's Yard and San Simeone Piccolo”. National Gallery Technical Bulletin 14 (1993): 34-41.

Eastaugh, Nicholas, Valentine Walsh, Tracey Chaplin, i Ruth Siddall. Pigment Compendium. A Dictionary and Optical Microscopy of Histoical Pigments. Amsterdam: Elsevier, 2008.

59 Np. popularne farby akrylowe, których spoiwem są akrylany w dyspersji. Do takiej konkluzji skłaniają rezultaty uzyskiwane w testach przeprowadzanych przez innych badaczy, dotyczących samego błękitu w tonach rozjaśnionych bielami w spoiwie olejnym, temperze jajowej, dyspersji akrylowej, gumie arabskiej, w których obserwowano zmiany. Patrz też przypis 52, 57. 
Ellis, David, Mike Eckhoff, i Vernon D. Neff. “Electrochromism in the Mixed - Valence Hexacyandes. 1. Voltametric and Spectral Studies of the Oxidation and Reduction of Thin Films of Prussian Blue”. Journal of Physical Chemistry 85 (1981) 9: 1225-1231. Encyclopédie Méthodique ou par ordre des matières orne des portraits de M.M. Diderot et d'Alembert. T. 1 Beaux-Arts. Paris-Liège: Charles-Joseph Panckoucke, Clément Plomteux, 1788.

Fiłatov, Viktor V. Restavracja nastiennoj masljanoj živopisi. Moskwa: Izobrazitel’noe Iskusstvo, 1995.

Hopliński, Jan. Farby i spoiwa malarskie. Wrocław: Ossolineum, 1990.

Itaya, Kingo, Tatsuaki Ataka, Toshima Shinobu, i Takeshi Shinohara. "Electrocchmistry of Prussian Blue, An in situ Moesbauer Effect Measurement”. Journal of Physical Chemistry 86 (1982) 13: 2415-2418.

Kiplik, Dimitri J. Technika živopisi. Moskva: Iskusstvo, 1960.

Kirby, Jo. "Fading and Colour Change of Prussian Blue: Occurrences and Early Reports". National Gallery Technical Bulletin 14 (1993): 62-71.

Kirby, Jo, i David Saunders. "Fading and Colour Change of Prussian Blue: Methods of Manufacture and the Influence of Extenders". National Gallery Technical Bulletin 25 (2004): 73-99.

Korenberg, Capucine. “The Photo-Ageing Behaviour of Selected Watercolour Paints Under Anoxic Conditions”. The British Museum Technical Research Bulletin 2 (2004): 49-57.

Rouchon Quillet, Véronique, Celine Remazeilles, Nguyen Thi Phuong, Jean Bleton, i Alain Tchapla. "The Impact of Gum Arabic on Iron Gall Ink Corrosion”. Restaurator 25 (2004) 4: 220-232.

Rudniewski, Piotr. Pigmenty i ich identyfikacja. Warszawa: ASP, 1995.

Samain, Louise. “Degradation Mechanism of Prusian Blue Pigments in Paint Layers”. Rozprawa doktorska, Université de Liège, 2012.

Samain, Louise, Fernande Grandjean, Gary J. Long, Pauline Martinetto, Pierre Bordet, i David Strivay, "Relationship between the Synthesis of Prussian Blue Pigments, Their Color, Physical Properties, and Their Behavior in Paint Layers”, Journal of Physical Chemistry 117 (2013) 19: 9693-9712.

Samain, Louise, Fernande Grandjean, Gary J. Long, Pauline Martinetto, Pierre Bordet, Jana Sanyova , i David Strivay. "Synthesis and Fading of Eighteenth-Century Prussian Blue Pigments: A Combined Study by Spectroscopic and Diffractive Techniques Using Laboratory and Synchrotron Radiation Sources”. Journal of Synchrotron Radiation 20 (2013): 460-473.

Saunders, David, i Jo Kirby. “The Effect of Relative Humidity on Artist's Pigments”. National Gallery Technical Bulletin 25 (2004): 62-72.

Sistino, Joseph A. “Ferrocyanide Pigments, Iron Blue”. W Pigment Handbook. T. 1, red. Temple C. Patton , 401-408. New York: A Wiley Interscience Publication, 1973. 
Slansky, Bohuslav. Technika malarstwa. T. 1 Materiały do malarstwa i konserwacji. Warszawa: Arkady, 1960.

Szmit-Naud, Elżbieta. „Stabilność barwna mieszanin pigmentów stosowanych we współczesnej palecie”. Ochrona Zabytków 3/4 (2004): 95-98.

Szmit-Naud, Elżbieta. „Wrażenie barwy i klasyfikacja barw. Ocena zmian barwy materiałów stosowanych w konserwacji dzieł sztuki”. Acta Universitatis Nicolai Copernici. Zabytkoznawstwo i Konserwatorstwo 43 (2005): 55-63.

Taguchi, Minori, Ichizo Yagi, Masaru Nakagawa, Tomokazu Iyoda, i Yasuaki Einaga. "Photocontrolled Magnetization of CdS-Modified Prussian Blue Nanoparticles". Journal of American Chemical Society 128 (2006) 33: 10980-10982. http://; nathan. instras.com/ResearchProposalDB/doc-123.pdf. Dostęp 1 marca 2016.

Tjutjunnik, Vasilij V. Materiały i technika živopisi. Moskva: Akademija chudožestv SSSR, 1962.

Vinner, Aleksiej V. Materiały živopisi. Moskva: Gosudarstvennoje izdatel’stvo Iskusstvo, 1954.

Watin, Jean-Félix. L'art du peintre, doreur et vernisseur. Paris: Grangé, Durand, 1776. http://gallica.bnf.fr/ark:/12148/bpt6k841821/f80.item.zoom. Dostęp 1 marca 2016. 


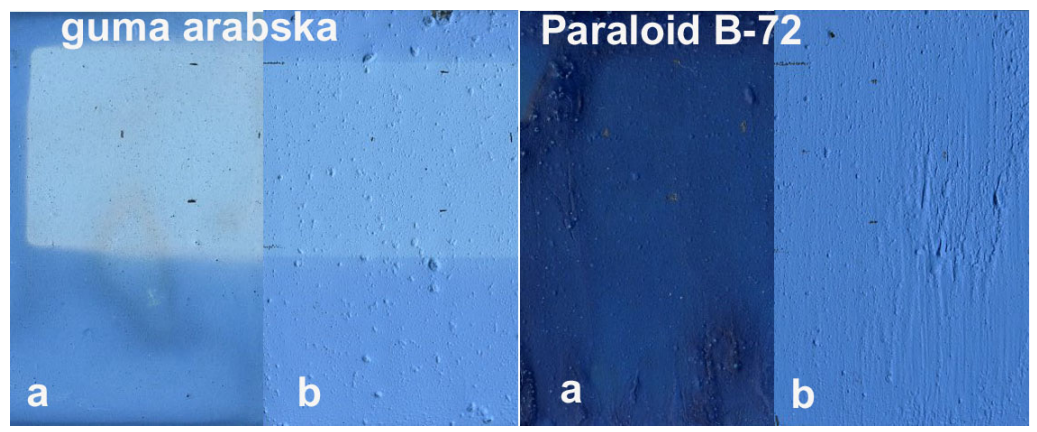

Il. 1. Zmiany barwy rozjaśnionych warstw błękitu pruskiego po pierwszym etapie starzenia. Fot. E. Szmit-Naud

a - błękit pruski z kredą bolońską, guma arabska; b - błękit pruski z bielą tytanową rutyl, guma arabska; c - błękit pruski z kredą bolońską, Paraloid B-72; $\mathrm{d}$ - błękit pruski z bielą tytanową rutyl, Paraloid B-72
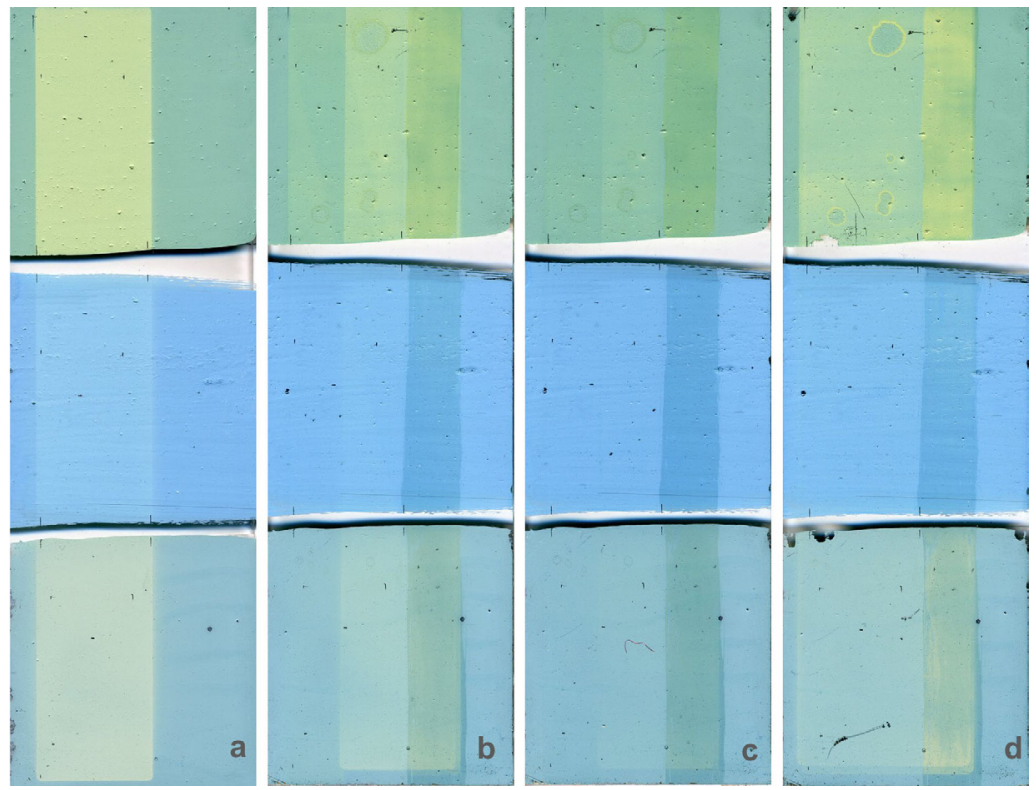

Il. 2. Przykład ewolucji zmian barwy warstw malarskich z mieszanin błękitu pruskiego z żółcienią kadmową, zielenią szmaragdową, sjeną naturalną rozjaśnionych dodatkiem bieli tytanowej (rutyl), w spoiwie z gumy arabskiej. Fot. E. Szmit-Naud $a$ - po pierwszym etapie starzenia; $b$ - po starzeniu, po przerwie, fragmentu eksponowanego w pierwszym etapie oraz werniksowanego; c - po dłuższej przewie i przechowywaniu w ciemności (78 dni); d - po zakończeniu przyspieszonego starzenia 

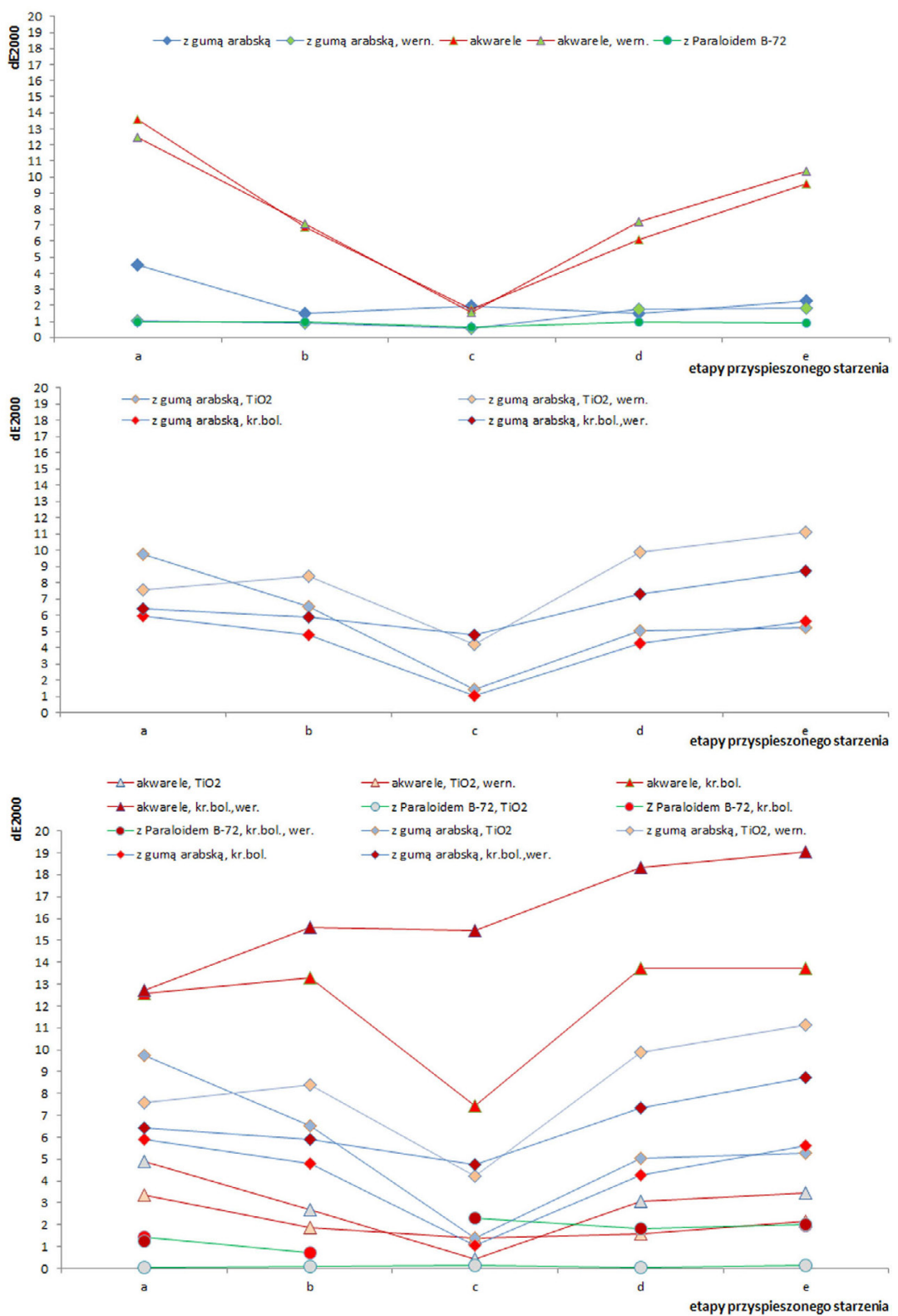

Il. 3. Przykład ewolucji zmian barwy warstw mieszanin błękitu pruskiego z żółcienią kadmową. Fot. E. Szmit-Naud

a - po pierwszym etapie starzenia; $\mathrm{b}$ - po kolejnym etapie podjętym po przewie; c - pomiar po dłuższej przewie (78 dni); d - po kolejnym etapie starzenia; e - po ostatnim etapie, podjętym po 10-dniowej przewie 


\section{PRZED STARZENIEM PO STARZENIU}

pole werniksowane

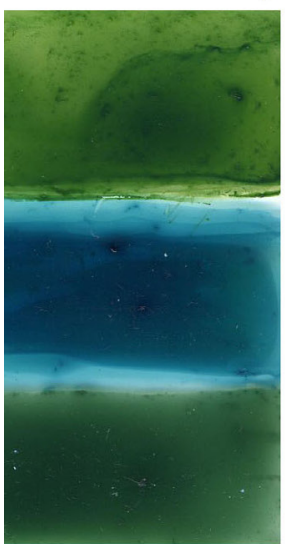

A
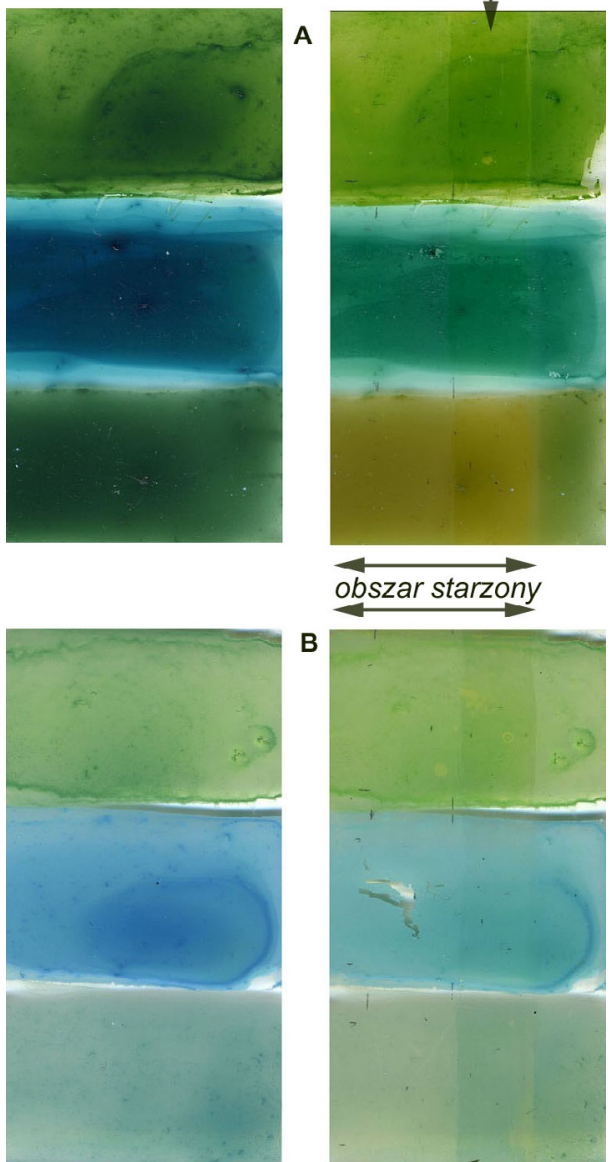

B

B

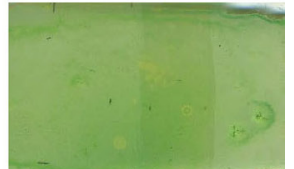

pole werniksowane
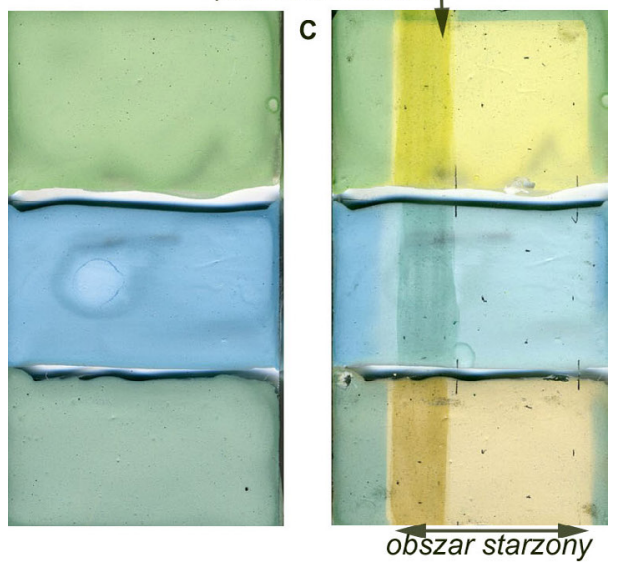

Il. 4. Zmiany barwy akwarelowych warstw malarskich z mieszanin błękitu pruskiego z żółcienią kadmową, zielenią szmaragdową, sjeną naturalną po zakończeniu przyspieszonego starzenia. Fot. E. Szmit-Naud a - bez dodatków rozjaśniających; $\mathrm{b}-\mathrm{z}$ bielą tytanową (rutyl); $\mathrm{c}-\mathrm{z}$ kredą bolońską 


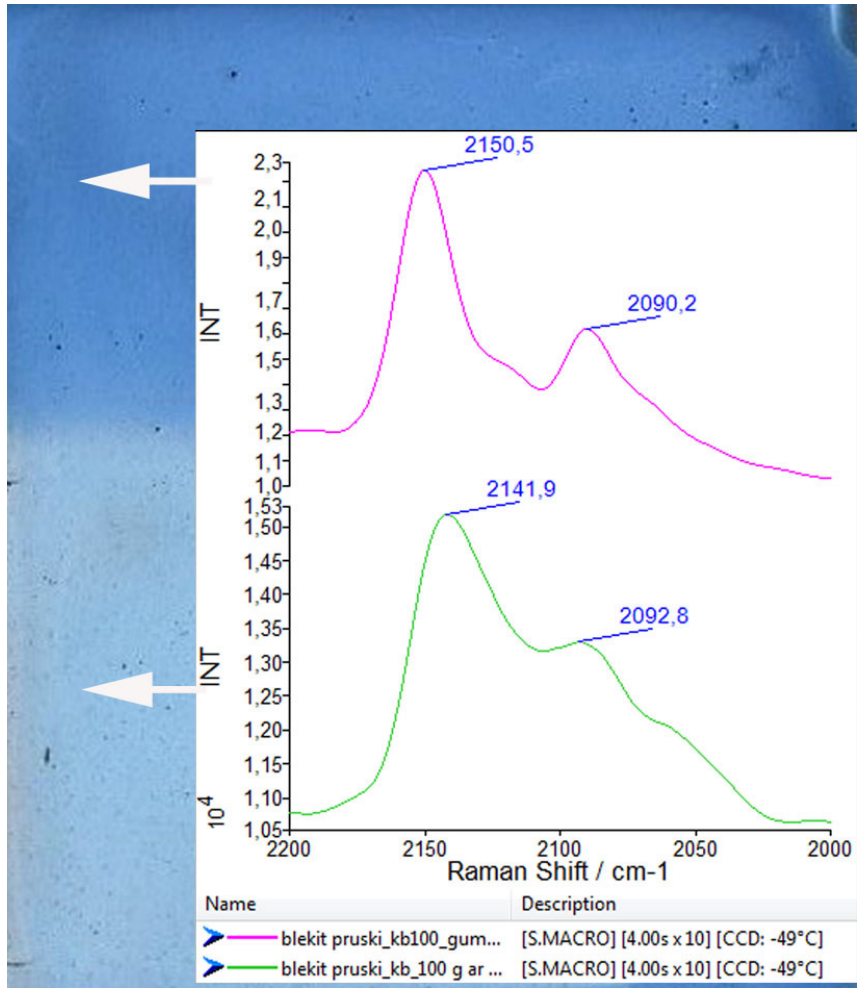

Il. 5. Zmiany barwy w warstwie błękitu pruskiego z kredą bolońską w spoiwie gumy arabskiej, wyniki w spektroskopii Ramana. Przesunięcie pasma drgań rozciągających $\mathrm{CN}^{-} \mathrm{z}\left[\mathrm{Fe}^{\mathrm{III}}(\mathrm{CN}) 6\right]^{3-} \mathrm{w}$ kierunku niższych częstotliwości może wskazywać na częściowe zachodzenie redukcji do $\left[\mathrm{Fe}^{\mathrm{II}}(\mathrm{CN}) 6\right]^{4}$. Fot. E. Szmit-Naud 

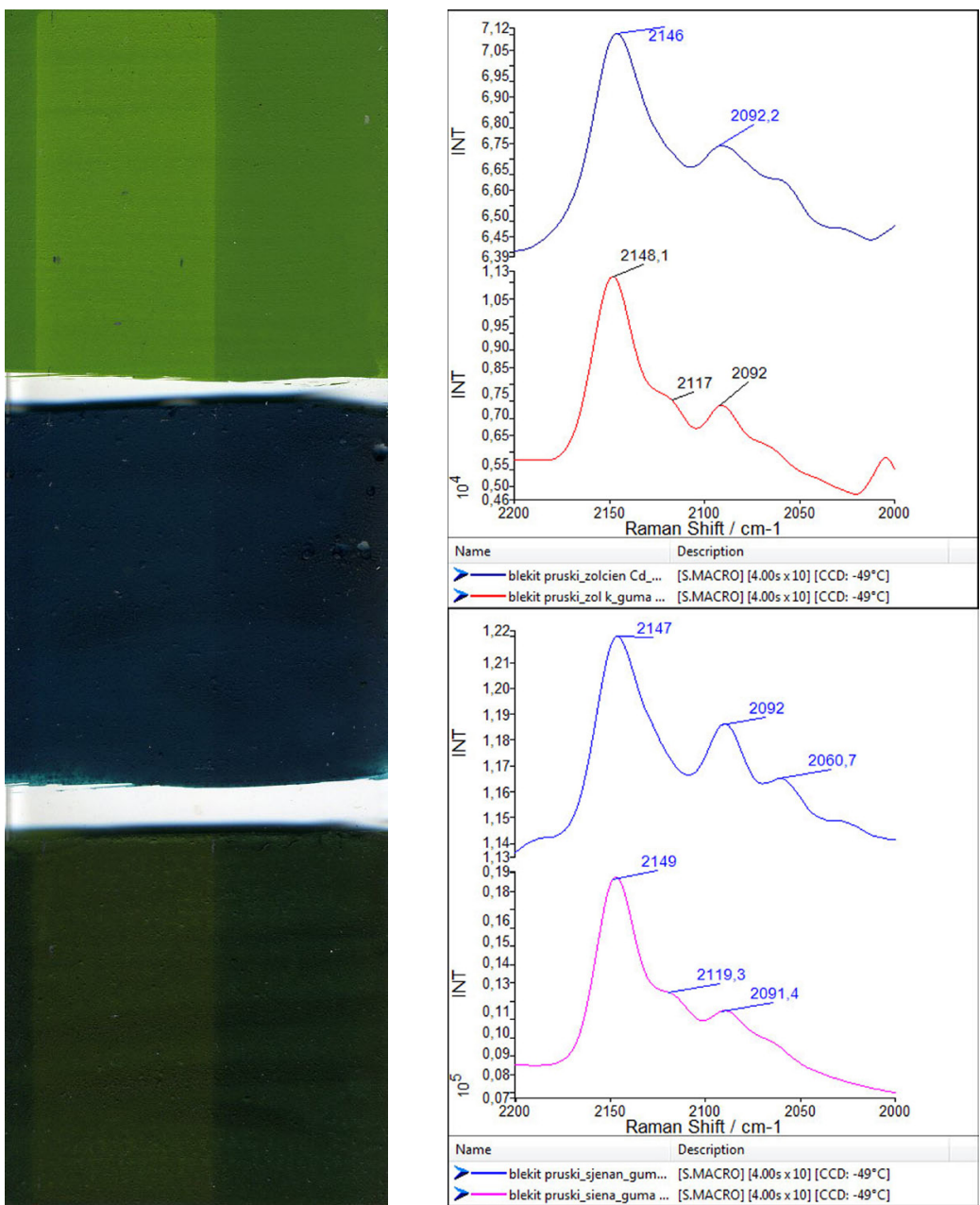

Il. 6. A: Warstwy malarskie w spoiwie z gumy arabskiej mieszanin błękitu pruskiego z żołcienią kadmową, zielenią szmaragdową i sjeną naturalną po pierwszym etapie starzenia. B: Wyniki analizy w spektroskopii Ramana warstw z żółcienią i sjeną naturalną. Nieznaczne zmiany widma (przesunięcie pasma drgań rozciągających $\mathrm{CN}^{-} \mathrm{z}$ [ $\left.\mathrm{Fe}^{\mathrm{III}}(\mathrm{CN}) 6\right]^{3-}\left(2146 \mathrm{~cm}^{-1}\right)$ w kierunku wyższych częstotliwości i zmiana $\mathrm{w} \sim 2060 \mathrm{~cm}^{-1}$ (pasm drgań rozciągających $\mathrm{CN}^{-}\left[\mathrm{Fe}^{\mathrm{II}}(\mathrm{CN}) 6\right]^{4-}$ ) oraz pojawienie się wyniesienia w ok. $2120 \mathrm{~cm}^{-1}$ mogą sugerować zachodzenie częściowego utleniania. Fot. E. Szmit-Naud 

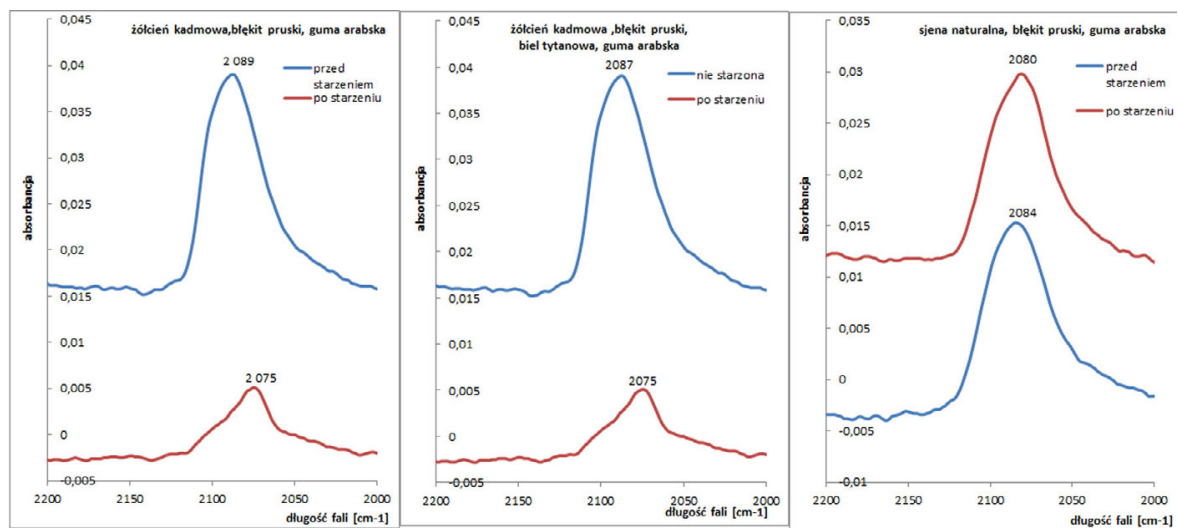

Il. 7. Wyniki analiz ATR FTIR kilku warstw malarskich o spoiwie z gumy arabskiej zawierających zielone mieszaniny błękitu pruskiego. Przesunięcie pasma może być symptomem redukcji

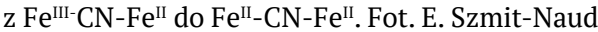

PRZED STARZENIEM
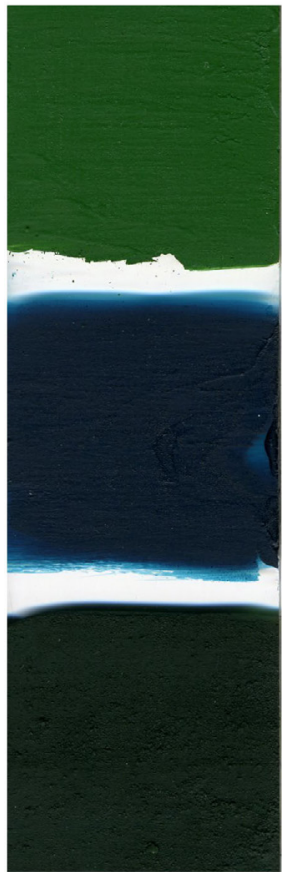

PO STARZENIU
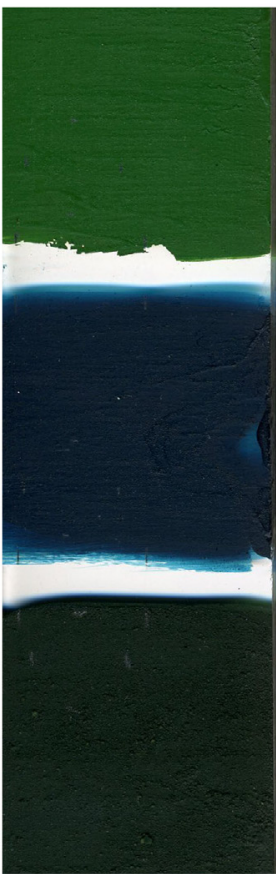
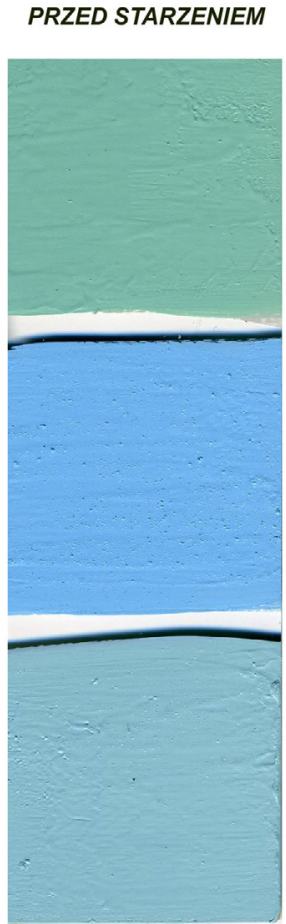

PO STARZENIU

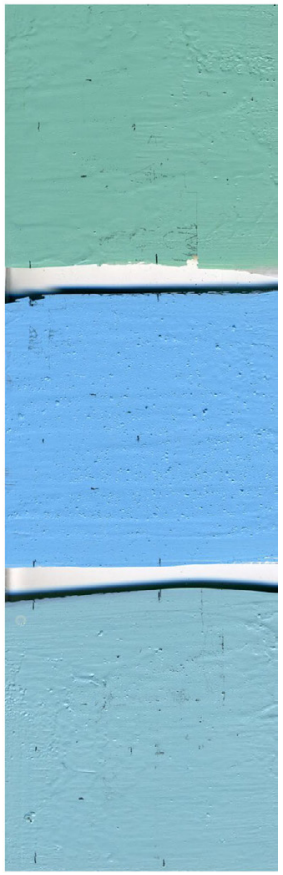

Il. 8. Warstwy malarskie z mieszanin błękitu pruskiego z żółcienią kadmową, zielenią szmaragdową, sjeną naturalną, ze spoiwem z Paraloidu B-72, bez dodatków i z bielą tytanową (rutyl). Brak widocznych zmian po starzeniu. Fot. E. Szmit-Naud 


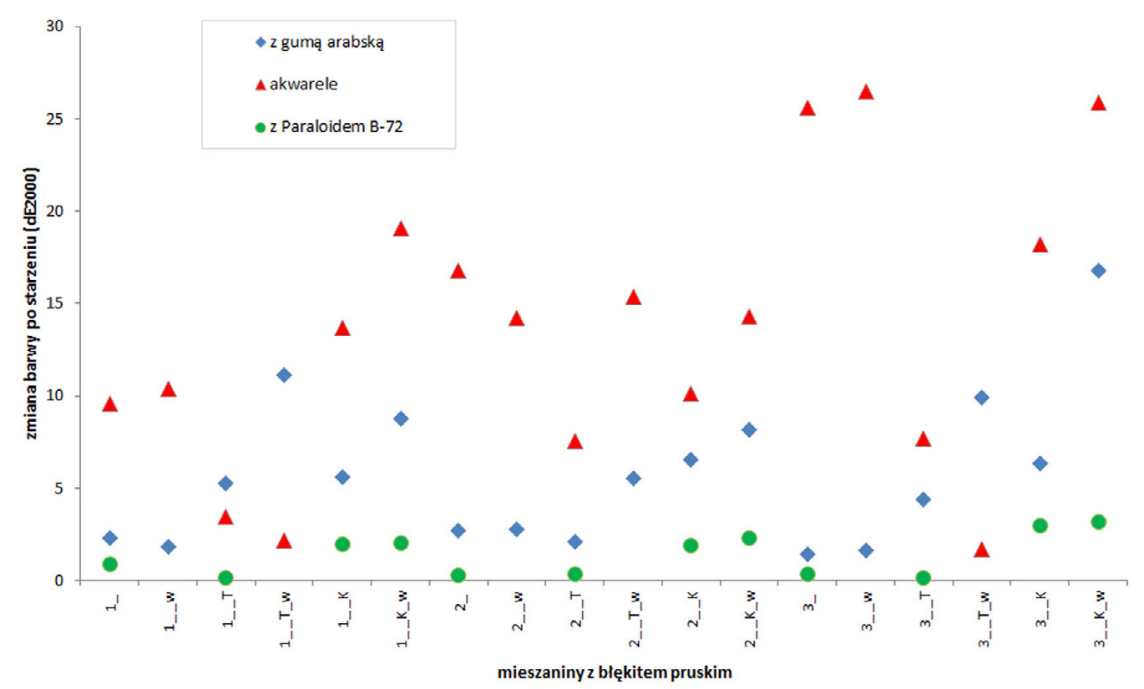

Il. 9. Zmiany barwy (dE 2000) warstw malarskich z badanych mieszanin z blękitem pruskim po zakończenu przyspieszonego starzenia. Fot. E. Szmit-Naud

1 - mieszaniny z żółcienią kadmową; 2 - z zielenią szmaragdową; 3 - ze sjeną naturalną; g - guma arabska; a - akwarela; P - Paraloid B-72; T - biel tytanowa; K - kreda bolońska; w - warstwa werniksowana 